\title{
Banking Progenitor Cells for Hippiatric Regenerative Medicine: Optimized Establishment of Safe and Consistent Cell Sources for Standardized Veterinary Therapeutic Protocols
}

\author{
Alexis Laurent ${ }^{1}$, Salim E Darwiche ${ }^{2,3}$, Nathalie Hirt-Burri ${ }^{1}$, Corinne Scaletta ${ }^{1}$, Murielle Michetti ${ }^{1}$, \\ Philippe Laurent ${ }^{4}$, Wassim Raffoul ${ }^{1}$, Anthony S de Buys Roessingh ${ }^{5 *}$ and Lee Ann Applegate ${ }^{1,2,6}$ \\ ${ }^{1}$ Musculoskeletal Medicine Department, Lausanne University Hospital, Switzerland
}

${ }^{2}$ Center for Applied Biotechnology and Molecular Medicine, University of Zurich, Switzerland

${ }^{3}$ Musculoskeletal Research Unit, Vetsuisse Faculty, University of Zurich, Switzerland

${ }^{4}$ Tec-Pharma SA, Veterinary Department, Switzerland

${ }^{5}$ Department of Pediatric Surgery, Lausanne University Hospital, Switzerland

${ }^{6}$ Oxford OSCAR Suzhou Center, Oxford University, PRC

*Corresponding author: Anthony S de Buys Roessingh, Pediatric Surgery Service, Lausanne University Hospital, CHUV, University of Lausanne, CH-1011 Lausanne, Switzerland.

To Cite This Article: Laurent A, Darwiche SE, Hirt-Burri N, Scaletta C, de Buys Roessingh AS. Banking Progenitor Cells for Hippiatric Regenerative Medicine: Optimized Establishment of Safe and Consistent Cell Sources for Standardized Veterinary Therapeutic Protocols. 2020 - 8(4). AJBSR.MS.ID.001284. DOI: 10.34297/AJBSR.2020.08.001284.

Received: 畊 April 03, 2020; Published: 畊 April 13, 2020

\begin{abstract}
Acute musculoskeletal injuries in large animals such as horses or camels often result in productivity losses and euthanasia in racing, esthetic or stock animal industries. Bioengineered products for tissue reconstruction and wound healing may supplement traditional veterinary surgical care synergistically. Banked primary fetal progenitor cells can potentially be used towards structural and functional therapeutic restoration in condensed timeframes. Extensive clinical experience exists in our University Hospital working with dermal progenitor fibroblasts for managing burns, donor site grafts and ulcers. By extrapolation, the present study assessed suitability of equine fetal progenitor cell sources for biotechnological processing, robust cell banking and application in tissue engineering strategies for hippiatric regenerative medicine. Diverse fetal equine musculoskeletal tissues were obtained and processed under defined frameworks and protocols for standardized and optimized tiered cell bank establishment and characterization. Consistency, safety and cyto-compatibility of progeny cells with therapeutic delivery systems were assessed. Finally, optimized hippiatric cell therapy protocols were applied for preliminary safety assessments and promoting musculoskeletal wound healing in four equine subjects. Equine progenitor cells were found to optimally adapt to standardized biotechnological processing, rapid extensive cell banking and consistent therapeutic construct bioengineering. Clinical applications of equine allogeneic cell therapies in large animals yielded preliminary evidence of safety and facilitated volumetric defect reconstruction or wound healing. Gathered experience around veterinary wound management using progenitor cells proved highly similar to therapeutic care of human patients suffering acute and chronic musculoskeletal affections. Standardized processing of a single organ donation and establishment of dedicated equine cell banks allows consistent and off-the-freezer allogeneic treatments to potentially be made available for millions of veterinary patients. Prior art in human translational regenerative medicine and preliminary evidence in veterinary settings strongly support the candidacy of equine progenitor cell banking as an optimal tool for efficient therapeutic management of diverse hippiatric musculoskeletal affections.
\end{abstract}

Keywords: Cell banking, cell therapy, hippiatric regenerative medicine, horses, musculoskeletal injuries, progenitor cells, tissue engineering, translational development, veterinary protocols, wound healing.

Abbreviations: CABMM: Center for Applied Biotechnology and Molecular Medicine; cATMP: combined Advanced Therapy Medicinal Product; CD: Cluster of Differentiation; CHUV: Centre Hospitalier Universitaire Vaudois; DED: De-Epidermized Dermis; DMEM: Dulbecco's Modified Eagle Medium; DMSO: Dimethyl Sulfoxide; ECM: Extracellular Matrix; EDTA: Ethylenediaminetetraacetic Acid; eFPC: equine Fetal Progenitor Cell; EGT: Exuberant Granulation Tissue; EOPCB: End of Production Cell Bank; ePBB: equine Progenitor Biological Bandage; ESC: Embryonic Stem Cell; FBS: Fetal Bovine Serum; GLP: Good Laboratory Practices; GMP: Good Manufacturing Practices; HA: Hyaluronic Acid; HE: Hematoxylin and Eosin; HLA: Human Leukocyte Antigen; MCB: Master Cell Bank; P/S: Penicillin-Streptomycin; PBB: Progenitor Biological Bandage; PBS: Phosphate Buffered Saline; PCB: Parental Cell Bank; PCR: Polymerase Chain Reaction; PDT: Population Doubling Time; PDV: Population Doubling Value; PEG: Polyethylene Glycol; Pn: Passage number; RNA: Ribonucleic Acid; RT: Room Temperature; TEP: Tissue Engineering Product; WCB: Working Cell Bank. 


\section{Introduction}

Degenerative diseases and acute wounds deeply impacting the musculoskeletal system often pave the way to the slaughterhouse for large animals such as horses or camels. Heavy burdens therefore ensue for individuals responsible for the animals, as productivity losses or direct losses in racing, esthetic or stock animal industries may bear significant impacts. Primordially, injury, pain and lameness directly impact animal patients themselves, prompting the development of efficient therapeutic strategies ideally solving wide arrays of veterinary affections [15]. In this context, application of novel tissue engineering and cell therapy concepts potentially allows for animal tissue repair and regeneration, attained through structural supplementation and balanced modulation of patient organisms towards physiological healing resurgence and stimulation thereof [6-13]. Bioengineered therapeutic products may supplement traditional veterinary surgical care synergistically and alleviate the resort to euthanasia [14-18]. Effective structural and functional restoration of equine musculoskeletal system components and effectors in condensed timeframes may be attainable by pragmatic application of emerging treatment strategies evaluated for human translational regenerative medicine such as cell therapies [19-26].

Development of clinical protocols for cutaneous or soft tissue repair and stimulation thereof in human and veterinary applications has rapidly evolved and currently comprises both autologous, allogeneic and xenogeneic products or procedures (Table 1) [2-
4,14-16,19-27]. Wide arrays of biological substrates and tissue sources have been studied with respect to suitability as starting materials for biomedical engineering, comprising but not limited to autologous biopsies, embryonic stem cells (ESCs), adult stem cells, bone marrow, cadaver tissue, acellular dermis, de-epidermized dermis (DED), xenografts, placenta and amniotic fluid [27-40]. Minimal technical processing requirements are prerequisites for consistent, effective and efficient cell source establishment, ranging from tissue procurement, culture initiation to progeny cell banking. Cultured primary fetal progenitor cells benefit from considerable industrial and clinical hindsight attesting safety and optimal adequation thereof with technical, economic and regulatory requirements of cell therapy product development. Extensive clinical experience exists in our University Hospital working with viable allogeneic dermal progenitor fibroblasts formulated as Progenitor Biological Bandages (PBBs) for managing burns, donor site grafts and chronic ulcers, yielding unique therapeutic results [41-50]. Wound healing rates after progenitor cell applications have been shown to be relatively more important and prompt with little scar tissue formation and an absence of immunogenic or tumorigenic properties has been documented [43,45-48]. Generalized and tissue-specific application of progenitor cell technology to musculoskeletal regenerative medicine has effectively been a local driver of translational biomedical research and is currently being evaluated for human and veterinary patients in Switzerland [5165].

Table 1: Comparison of various cell types or approaches for equine or human cell therapy and tissue engineering with examples, associated advantages and inconveniences.

\begin{tabular}{|c|c|c|c|}
\hline \multicolumn{2}{|r|}{ Cell Type } & Advantages & Inconveniences \\
\hline 1 & Autologous & No immune rejection & $\begin{array}{c}\text { Biopsy necessary } \\
\text { Limited differentiation capacities } \\
\text { Limited manufacture scale-up } \\
\text { Limited number of tissues } \\
\text { Poor expansion capacities } \\
\end{array}$ \\
\hline 1.1 & Adult stem cells & $\begin{array}{l}\text { Autologous source } \\
\text { Few ethical concerns }\end{array}$ & Same as above \\
\hline 2 & Allogeneic & $\begin{array}{l}\text { No autologous biopsy } \\
\text { Same-species source }\end{array}$ & $\begin{array}{l}\text { Immune incompatibility } \\
\text { Scarcity for some tissues } \\
\text { Transfer of adventitious agents }\end{array}$ \\
\hline 2.1 & Embryonic stem cells & $\begin{array}{l}\text { High differentiation capacities } \\
\text { "Immortal" }\end{array}$ & $\begin{array}{c}\text { Difficult control of cell growth } \\
\text { Expensive and difficult cell culture/differentiation } \\
\text { High ethical concerns } \\
\text { Inhomogenous cell growth } \\
\text { Limited availability } \\
\text { Some immune incompatibility }\end{array}$ \\
\hline 2.2 & Fetal progenitor cells & $\begin{array}{c}\text { Consistency and stability } \\
\text { Extensive cell banking } \\
\text { High biocompatibility } \\
\text { Low direct costs } \\
\text { Low immunogenicity and tumorigenicity } \\
\text { Safety testing } \\
\text { Single organ donation } \\
\text { Tissue-specific cell types }\end{array}$ & Stringent selection process for mother-donor \\
\hline
\end{tabular}




\begin{tabular}{|c|c|c|c|}
\hline 3 & Xenogeneic & High availability & $\begin{array}{c}\text { Functional loss after transplant } \\
\text { Immune incompatibility } \\
\text { Transfer of adventitious agents }\end{array}$ \\
\hline 3.1 & Transgenic animals ("humanized") & $\begin{array}{c}\text { Genetically controlled } \\
\text { High availability } \\
\text { Immune compatibility }\end{array}$ & Genetically controlled \\
\hline
\end{tabular}

The present work is consistent with the One Health Initiative (www.onehealthinitiative.com), an approach of integrative medicotherapeutic development under which veterinary medicine can benefit from human medicine and vice versa. By extrapolation of acquired experience in progenitor cell banking and current insights into human translational regenerative medicine, it was hypothesized that progenitor cell therapies might vastly benefit hippiatric musculoskeletal medicine. Indeed, within the sports industry alone, high incidence of equine cutaneous, flexor tendon and suspensory ligament injuries requiring heavy therapeutic intervention is explained by relatively high exposure to potentially traumatic events and results in numerous veterinary consultations and follow-ups. Specificities of equine cutaneous and soft tissue injury (in particular to distal limbs) comprise relatively long and complicated healing periods lengthened by frequent impracticality of effective suturing after volumetric tissue prejudice $[2,3,5]$. Additionally, horses are predisposed to excessive tissue granulation, which inhibits tissue repair processes mediated by epithelial formation and promote exuberant granulation tissue (EGT) formation $[1,13,16,18]$. Such outcomes are poorly controlled by existing non-biological wound care products (Table 2). Resulting consequences for race animals comprise extensive immobilization periods (> 2-6 months), diminished esthetic quality assorted to lessened financial or sporting value and often lead to subject revalorization for breeding or euthanasia. Direct necessity therefore prompts the development of effective therapeutic products capable of rapidly stimulating epidermal and soft tissue renewal while limiting excessive EGT formation in equine injuries $[5,15,18]$.

\begin{tabular}{|c|c|c|c|}
\hline Technique & Product (manufacturer) & Advantages & Inconveniences \\
\hline \multirow{5}{*}{ Sutures } & Vicryl ${ }^{\circledR}$ (Ethicon Inc., braided) & Good tension resistance & Strong vector for bacterial infection \\
\hline & PDS $^{\circledast}(J \& J$, resorbable $)$ & $\begin{array}{l}\text { Good resistance for tension } \\
\text { Low infection risk }\end{array}$ & NA \\
\hline & PROLENE $^{\circledast}(J \& J$, non-resorbable) & $\begin{array}{l}\text { Good resistance for tension } \\
\text { Low infection risk }\end{array}$ & Possible inflammatory reaction \\
\hline & Cutaneous staples (Ethicon Inc.) & $\begin{array}{l}\text { Diminished inflammation } \\
\text { Low infection risk }\end{array}$ & Relatively expensive \\
\hline & Biological glue(diverse) & Low inflammation & $\begin{array}{c}\text { Limited use } \\
\text { Relatively expensive }\end{array}$ \\
\hline \multirow{3}{*}{ Bandages (absorbent) } & JELONET $^{\circledR}$ (Smith and Nephew) & Good absorption & $\begin{array}{l}\text { Induces tissue granulation } \\
\text { Inhibits epithelialization }\end{array}$ \\
\hline & MELOLIN $^{\circledR}$ (Smith and Nephew) & \multirow{2}{*}{$\begin{array}{l}\text { No interference with } \\
\text { epithelialization }\end{array}$} & \multirow{2}{*}{ Limited absorption capacity } \\
\hline & SKINTACT $^{\circledR}$ (Robinson Healthcare) & & \\
\hline \multirow{2}{*}{ Bandages (occlusive) } & OPSITE $^{\circledR}$ (Smith and Nephew) & \multirow{2}{*}{$\begin{array}{l}\text { Enhances quality and rate of } \\
\text { healing }\end{array}$} & \multirow{2}{*}{ Favorizes bacterial proliferation } \\
\hline & TEGADERM $^{\mathrm{TM}}\left(3 \mathrm{M}^{\mathrm{TM}}\right)$ & & \\
\hline NA-Non-Applicable & & & \\
\hline
\end{tabular}

Intrinsic technological and therapeutic advantages of cultured primary progenitor cells enable standardized, safe and consistent processing of biological materials and subsequent widespread clinical application of optimized treatment protocols. Fetal progenitor cells are tissue-specific and do not require either biochemical manipulation to maintain their respective defined phenotypes nor feeder-layers to sustain in vitro proliferation, allowing for standard optimized cell banking consistency $[43,45,53,66]$. Extensive proliferation capacities, low immunogenicity and tumorigenicity, high cyto and biocompatibility and excellent stability allow for tangible therapeutic product development based on primary progenitor cell sources $[43,46$ -
49]. Such an objective is attainable through the establishment of extensive qualified tiered cell banks which can potentially benefit millions of veterinary patients. Indeed, a robust dedicated cell bank derived from a single equine-fetal organ donation fragment $<<1$ $\mathrm{cm}^{3}$ ) potentially yields sufficient progeny materials for industrial scale manufacturing of bioengineered therapeutic constructs $\left(>10^{9}\right.$ constructs/cell bank) [47].

Vast experience and hindsight in progenitor cell technology for human translational regenerative medicine supported preliminary investigation of equine fetal progenitor cells (eFPCs) as candidates for efficient therapeutic management of diverse hippiatric musculoskeletal injuries. The present study aimed for suitability 
assessment of eFPC sources for biotechnological processing, robust cell banking and application in tissue engineering strategies for hippiatric regenerative medicine. Diverse codified fetal equine musculoskeletal tissues (skin, muscle, cartilage, tendon, connective tissue and bone) were obtained after pregnancy terminations and processed under defined frameworks and protocols for standardized and optimized tiered cell bank establishment and characterization. Consistency, safety and cyto-compatibility of progeny eFPCs with therapeutic delivery systems (collagen sheets and hyaluronic acid (HA) gels) were assessed. Finally, optimized hippiatric cell therapy protocols were applied for preliminary assessment of safety and promotion of musculoskeletal wound healing in four equine subjects. This work establishes technical suitability of eFPCs for bioengineered product manufacturing and preliminary safety evidence of allogeneic primary equine progenitor cell application in hippiatric patients. Data presented herein supports further investigation of equine progenitor cell therapy in vivo within standardized veterinary settings and further broadening of the potential scope of application of allogeneic progenitor cell therapy in the developmental domain of translational musculoskeletal regenerative medicine.

\section{Materials and Methods}

All procedures involving animal patients (organ donation/ biopsy procurement and experimental treatments) were performed with appropriate informed consent from respective animal owners and in compliance with the Swiss Federal Veterinary Office guidelines based on the Swiss Federal Law on Animal Welfare and applicable ordinances. Experimental treatments were prescribed and administered by practicing veterinarians as veterinary magistral preparations as defined by the Swiss Federal Law on Therapeutic Products. Animal procedures were carried out in a private veterinary practice in Boudevilliers, Switzerland.

\section{Equine fetal tissue procurement}

Two mother-donors (codenames ED001 and ED002) for equine fetal tissue donation were identified by veterinarians tending to spontaneous pregnancy interruptions in Western Switzerland. ED001 was a female 7-year-old German Warmblood (Oldenburger), while ED002 was a female 10-year-old German Coldblood (Noriker). Following gestational termination and expulsion of the fetuses/foals, veterinarians proceeded with full physical examination of the mother-donors, which revealed no physical and physiological abnormalities or diseases. No particular cause was attributed to either of both pregnancy interruptions. Fetal tissue donations (whole fetus in placenta) were wrapped in surgical mats and kept on wet ice before rapid subsequent (< 6 hours) detailed investigation and processing by veterinarians and biologists. Gestational ages, total weights and lengths of donations were established after thorough rinsing with sterile normal saline (Bichsel, Switzerland). Macroscopic and microscopic examinations (micro-dissection and histology) were performed on both donations. Various musculoskeletal tissue fragments were isolated and procured for biotechnological processing and cell type derivation. Each tissue fragment was surgically cleaned of any unwanted adherent tissue, thoroughly rinsed with sterile normal saline, aseptically placed in a sterile dedicated labelled cell culture-grade recipient (50 mL tube, Falcon ${ }^{\circledast}$, USA) and immersed in $30 \mathrm{~mL}$ phosphate buffered saline ( $\mathrm{PBS}, \mathrm{KH}_{2} \mathrm{PO}_{4} 0.21 \mathrm{~g} / \mathrm{L}, \mathrm{NaCl} 9.0$ $\mathrm{g} / \mathrm{L}, \mathrm{Na}_{2} \mathrm{HPO}_{4} 0.726 \mathrm{~g} / \mathrm{L}$, Invitrogen ${ }^{\mathrm{TM}}$, USA) supplemented with $1 \%$ penicillin-streptomycin (P/S, $100 \mathrm{U}$, Sigma-Aldrich, Switzerland) for rapid transport $(<2$ hours) to the cell culture laboratory in a refrigerated container $\left(4^{\circ} \mathrm{C}\right)$.

\section{Enzymatic tissue processing, culture initiation and equine PCB establishment}

After transfer to an independent Good Laboratory Practices (GLP) cell culture laboratory, individual tissue biopsies were serially washed 4 times for 15 minutes each in PBS supplemented with $1 \% \mathrm{P} / \mathrm{S}$. Biopsies were then transferred to fresh sterile culturegrade tubes and were incubated for 10-25 minutes (depending on the tissue) in $25 \mathrm{~mL}$ trypsin-EDTA (0.25\% trypsin - $0.1 \%$ ethylene diaminetetra acetic acid, Gibco ${ }^{\star}$, USA) at room temperature (RT). Tissues were subsequently individually and aseptically dissected into $<0.5 \mathrm{~mm}^{3}$ fragments and transferred to sterile tissue culture Petri dishes (10 cm diameter, Falcon ${ }^{\oplus}$, USA). Culture dishes were sterilely and deeply scored following checkerboard patterns using scalpels. In order to initiate adherent cell culture, isolated tissue fragments were homogenously distributed and further mechanically attached along scored plastic regions by gentle additional mincing. For each individual tissue biopsy, 6-10 Petri dishes were planted with tissue fragments ( $~ 5-10$ fragments/ dish). A small volume $(<2 \mathrm{~mL})$ of sterile warm $\left(37^{\circ} \mathrm{C}\right)$ liquid growth medium was dispensed around individual fragments to avoid initial tissue flotation. The growth medium was composed of Dulbecco's Modified Eagle Medium containing phenol red, $25 \mathrm{mM}$ dextrose, 1 mM sodium pyruvate and L-glutamine (DMEM, Invitrogen ${ }^{\mathrm{TM}}$, USA) supplemented with $10 \% \mathrm{v} / \mathrm{v}$ clinical grade fetal bovine serum (FBS, HyClone ${ }^{\mathrm{TM}}$, USA) and $2 \mathrm{mM}$ L-glutamine (Invitrogen ${ }^{\mathrm{TM}}$, USA). All media had been tested for sterility before use. Tissue culture dishes were gently transferred in a humidified incubator set at $37^{\circ} \mathrm{C}$ and $5 \% \mathrm{CO}_{2}$. After the first 24 hours of incubation, additional warmed growth medium ( $8 \mathrm{~mL}$ ) was cautiously added by slow dispensing to each culture vessel, without disturbing the adherent tissue fragments, before reincubation. Growth medium did not contain antibiotic supplementation and was thereafter exchanged every other day. Once the adherent cultures had migrated outwards from the tissue fragments and attained $90 \%$ confluency, cells were harvested as described hereafter.

Each culture dish was rinsed twice with $5 \mathrm{~mL}$ warmed PBS and cell monolayers were enzymatically detached using $2 \mathrm{~mL}$ trypsin- 
EDTA. Following complete cellular detachment and cell colony separation, resulting suspensions were pooled and diluted with equal volumes of growth medium. Using $500 \mu \mathrm{L}$ aliquots of the pool, manual enumeration using a Neubauer Improved hemocytometer and Trypan Blue exclusion dye (Sigma-Aldrich, Switzerland) yielded total and viable cell counts. The cell suspension pool was then centrifuged at $230 \times g$ for 15 minutes. Supernatants were discarded and cell pellets were re-suspended in $50 \mathrm{~mL}$ warmed growth medium. The pooled suspension was further diluted with growth medium and dispensed homogenously into 80 vented T175 cell culture flasks $\left(175 \mathrm{~cm}^{2}\right.$, Nunc $\left.{ }^{\circledR}, \mathrm{USA}\right)$. The relative viable seeding density in culture flasks was of $2 \times 10^{3}$ cells $/ \mathrm{cm}^{2}$, while the final total volume of growth medium was of $30 \mathrm{~mL} / \mathrm{T} 175$. Seeded culture vessels were incubated and growth medium was exchanged as previously described until cell confluency attained 100\%. Cultures were then harvested by trypsinization and cells were enumerated as previously described. A single pooled cell suspension was then centrifuged for 15 minutes at $230 \mathrm{x} g$. After supernatant discard, the cell pellet was resuspended in a cryopreservation solution composed of DMEM, FBS and dimethyl sulfoxide (DMSO, SigmaAldrich, Switzerland) in 5:4:1 volumetric proportions while the cell quantity was adjusted at a final viable cellular density of $5 \times 10^{6}$ cells/mL. The resulting suspension was subsequently homogenously and aseptically aliquoted in labelled cryovials (1.8 $\mathrm{mL}$ capacity, Nunc ${ }^{\circledR}$ CryoTube $\left.{ }^{\circledR}, 1.1 \mathrm{~mL} / \mathrm{vial}\right)$. Vials were then placed in Nalgene ${ }^{\otimes}$ Mr. Frosty ${ }^{\circ}$ Cryo $1^{\circ} \mathrm{C}$ Freezing Containers or CoolCell ${ }^{\circ}$ FTS30 devices $\left(-1^{\circ} \mathrm{C} /\right.$ minute rate of cooling, Nalgene $e^{\infty}$, UK and Corning ${ }^{\circledR}$, USA) and were rapidly transferred to a $-80^{\circ} \mathrm{C}$ ultra-low temperature freezer. After 24 hours, cryovials were transferred to liquid nitrogen vapor phase $\left(-165^{\circ} \mathrm{C}\right)$ in dedicated Dewar tanks for long-term storage. Cryovials were stored in separate level-alarm fitted containers in several independant locations to mitigate destruction risks. This cryopreserved material was defined as an equine Parental Cell Bank (PCB).

From this initial PCB homogenous cell stock, progeny tiered cell banks could be further derived, comprising full Master Cell Banks (MCBs), Working Cell Banks (WCBs) and End of Production Cell Banks (EOPCBs). To perform serial expansions and create progeny cell stocks, PCB vials were removed from the storage tank and transported to the cell culture suite on dry ice (without direct contact between the ice and the vials). For each specific cell type, one vial was initiated by rapid thawing in a $37^{\circ} \mathrm{C}$ waterbath, followed by rinsing of the cells in warmed culture medium before seeding in 10-15 T175 culture flasks at a relative viable cell density of $2 \times 10^{3}$ cells $/ \mathrm{cm}^{2}$. To do so, viable counts were determined upon initiation and the acceptance criteria was set at $85 \%$ relative viability for the initiation procedure to continue. Culture expansions were conducted as described previously and harvested cells were homogenously distributed and cryopreserved with $2 \times 10^{6}$ to $10^{7}$ viable cells/vial.

\section{eFPC banks safety assessment}

For each specific cell type, safety testing was performed on 1 vial from the start, middle and end portions of the MCBs. Vials were initiated and cells were expanded in culture for the experiments. Bacterial contamination was excluded after one week of culture based on microscopical aspects of cultures and color of the growth medium (presence of phenol red indicator). Mycoplasma absence was verified by polymerase chain reaction (PCR, Look Out ${ }^{\circledR}$ Mycoplasma PCR Detection Kit, Sigma-Aldrich, Switzerland). Presence of equine prions was not investigated. Presence of bovine and porcine adventitious agents was excluded based on the certificates of analysis provided for FBS and trypsin-EDTA.

\section{In vitro eFPCs characterization, expansion kinetics and lifespans}

Differential characterization of the various primary equine progenitor cell types was performed by microscopic observation. Vials of the different equine cell types of interest (isolated from skin, muscle, cartilage, tendon, connective tissue and bone from both organ donations) at different passages were used to obtain standard growth curves. Statistically significative differences in cell yields were determined by Student's t-test, $\mathrm{p}<0.05$. In brief, vials were initiated, viable counts were determined, cells were seeded at a relative viable density of $2 \times 10^{3}$ cells $/ \mathrm{cm}^{2}$ in T75 sterile and uncoated culture flasks $\left(75 \mathrm{~cm}^{2}, \mathrm{Nunc}^{\oplus}\right.$, USA) in $10 \mathrm{~mL}$ of growth medium and cultures were maintained as described previously. At various time points $(1,3,5,7$ and 9 days), cells were harvested and total viable counts were determined to constitute growth curves. Experiments were conducted in triplicate with four experimental repetitions. In any case, cultures were harvested for enumeration and viability assessment after reaching $80 \%$ confluency. Population doubling values (PDVs) of each cell type at different passages were calculated using the following formula:

$$
P D V=3.32 \cdot \log _{10} \frac{N_{H}}{N_{S}}
$$

Whereas $\mathrm{N}_{\mathrm{H}}$ is the total viable cell count at the time of harvest and $\mathrm{N}_{\mathrm{S}}$ is the total viable cell count at the time of seeding the cells in the culture vessels. Assorted population doubling times (PDTs) expressed in hours were calculated using the following formula:

$$
P D T=\frac{T_{I}}{P D V}
$$

Whereas $\mathrm{T}_{\mathrm{I}}$ is the total incubation time expressed in hours from the time of seeding to the time of initiation of the harvest procedure and PDV is the population doubling value determined for the specific considered expansion. To assess stability of the equine cell banks during cryopreservation, the experiments were repeated after eight years of storage, whereas experiments were conducted in triplicate with three experimental repetitions. 
The in vitro lifespans of the considered cell types were assessed with regard to passage numbers. Cells were serially cultured, using relative viable seeding densities of $2 \times 10^{3}$ cells $/ \mathrm{cm}^{2}$, in T75 vented culture flasks ( $\mathrm{Nunc}^{\circ}$, USA) following expansion and harvest procedures (passage at $80 \%$ cell confluency) described previously until reaching passage 10 (P10). Total and viable cell counts were determined at each passage. The in vitro lifespan was defined as the highest passage at which the growth rates (expressed as relative cell yields or PDVs) conserved 75\% of initial values (established as average values over three low passages, P2-P4).

\section{Equine Progenitor Biological Bandage preparation and study}

To manufacture equine PBBs (ePBBs) for in vitro investigation and experimental clinical application, skin and muscle equine progenitors from the 3-month gestational age donation (ED001SK, ED001-Mu) were used. Vials from respective WCBs (P5) were thawed, cells were rinsed in warmed growth medium and viable counts were determined, as previously described. A registered medical device (Tissue Fleece ${ }^{\circledR}$, Baxter AG, Switzerland) consisting of a dry weight $9 \mathrm{~cm} \times 12 \mathrm{~cm}$ equine collagen sheet of $2 \mathrm{~mm}$ thickness was used as a scaffold. The bandages were aseptically transferred in large Petri dishes (15 cm diameter, Falcon ${ }^{\circledR}$, USA) and small incisions were made at $2 \mathrm{~cm}$ intervals into the collagen matrix with a sterile, small bored Pasteur pipette. Skin and muscle progenitor cell suspensions were pooled at a 1:1 viable cell ratio. Cells were then seeded on the matrix by gentle dispensing, with the final suspension volume being $20 \mathrm{~mL}$ and the relative viable cell seeding density on the constructs being $5 \times 10^{3}$ cells $/ \mathrm{cm}^{2}$. Culture vessels were incubated as described previously. An additional volume of $30 \mathrm{~mL}$ of warmed growth medium was dispensed in each vessel after 1 hour of incubation. Incubation was continued and medium exchanges occurred every other day for a period of 30 days.

At time-points ranging between 4 days and 30 days of culture, constructs were snap-frozen in liquid nitrogen and processed for histology. Construct sections of $20 \mu \mathrm{m}$ were stained with hematoxylin and eosin (HE solution, Sigma-Aldrich, Switzerland) for morphological analysis and evaluation of cyto-compatibility, cell integration and distribution. Evolutive assessment of cell viability and proliferation in the collagen scaffolds was performed between days 1 and 9. In order to dissociate cells from the matrix for enumeration, the constructs were incubated for a period of 30 minutes at $37^{\circ} \mathrm{C}$ after treatment with a solution of trypsin-EDTA and collagenase (collagenase type II, Clostridium histolyticum, Gibco ${ }^{\mathrm{TM}}$, USA). After complete degradation of the collagen structure, cells were rinsed, collected by centrifugation as described previously and isolated for enumeration (total and viable cell counts). Experiments were performed in triplicate and in three experimental repetitions.

\section{Hydrogel for equine fetal progenitor tenocyte delivery}

To manufacture a cell delivery hydrogel vehicle yielding equine fetal progenitor tenocytes for in vitro investigation, tendon progenitors from the 3-month gestational age donation (ED001Ten) were used. Vials from respective WCBs (P5) were thawed, cells were rinsed in warmed growth medium and viable counts were determined, as described previously. A registered medical device (Mesolis $^{\mathrm{TM}}$, Anties SA, Switzerland) consisting in highly reticulated HA (2\%) was used as a scaffold. Cyto-compatibility between the progenitor tenocytes and the injectable hydrogel scaffold was assessed by evolutive investigation of cell survival and growth characteristics. To do so, standard doses of $10^{4}$ viable cells were dispersed in $0.5 \mathrm{~mL}$ hydrogel by re-suspension after centrifugation of cell suspensions at $230 \mathrm{x} g$ during 15 minutes. The constructs were then transferred to 6 and 24-well culture microplates (Nunc ${ }^{\oplus}$, USA) and placed in incubation as previously described. Cell morphology was monitored daily and recorded by direct photographic imaging through the transparent construct. Cell counts were performed regularly between days 1 and 9 by dilution of the samples from the 24-well plates in DMEM, trypsinization of the assay wells, rinsing and pooling of the cells and subsequent viable count determination.

\section{Clinical applications of ePBBs}

Manufactured ePBBs were clinically applied to equine patients for preliminary assessment of safety (absence of immune rejection or tumor formation) and healing rate stimulation potential. Four clinical cases were identified by veterinarians as requiring special therapeutic care and characterized by mitigated structural and functional recovery prognoses based on professional practical experience. Two of these experimental clinical cases treated in Boudevilliers (Switzerland) are presented herein. The first case consisted in a profound articular lesion on the right hind knee of a 1-year-old female pony (French Saddlebred Pony) following a severe fall against barbed wire on difficult terrain. The wound was around $4 \mathrm{~cm}$ in diameter, $3 \mathrm{~cm}$ in depth with exposure of tendons, bone and important volumetric soft-tissue loss. The location of the lesion and its extent negated the possibility of direct suture.The second case consisted in a mandibular injury in a 3-year-old male Franche-Montagne horse. Abnormal growth of a tooth had caused a dental infection and ulceration of the lower left molar lodge, resulting in a transfixing lesion (external fistula) in the peri-buccal region lined with necrotic tissue negating the possibility of direct suturing. Both patients were treated with a combination of classic veterinary surgery and application of bioengineered ePBBs to close and heal respective severe wounds.

\section{Results}

\section{Equine fetal tissue procurement}

Both tissue donations (ED001 and ED002, same code-names as mother-donors) were examined by experienced veterinarians and biologists. Gestational ages, total weights and lengths (without placenta, measurement from head to hind legs) of donations were established at three months, $103.5 \mathrm{~g}, 15 \mathrm{~cm}$ for ED001 and 11 months, $29.5 \mathrm{~kg}$, $81 \mathrm{~cm}$ for ED002, respectively. Macroscopic and microscopic examinations allowed for confirmation of anatomical 
normality and absence of observable physical or physiological defects. Micro-dissection and histology yielded no evidence of major abnormalities of the cardiovascular, respiratory, endocrine, digestive, urogenital, musculoskeletal or central-nervous systems. Several distinct and very specific tissue fragments were individually isolated during aseptic micro-dissection, acquired and separately conditioned, including skin (abdomen, region without hair growth), muscle (thigh region), cartilage (cartilage-fetlock joint, covering distal epiphysis of the metacarpal bone), tendon (superficial digital flexor tendons, mid-metacarpal region), connective tissue (diaphragm region) and bone (trabecular, distal metacarpal bone) (0.2-2 $\mathrm{cm}^{3}$ of tissue/organ/donation) (Figure 1).

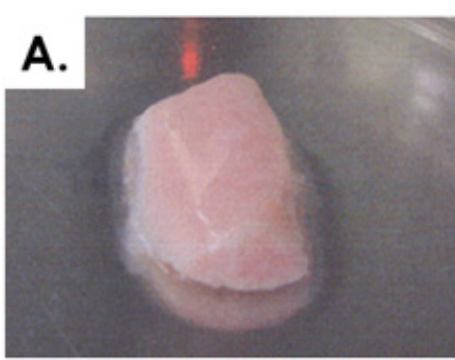

Tendon

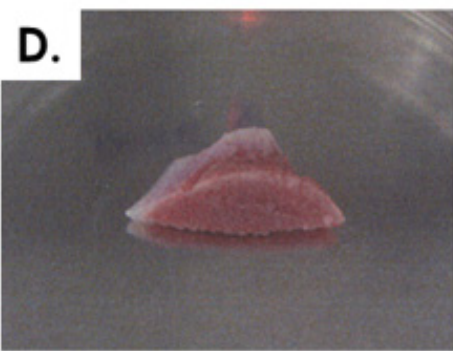

Bone

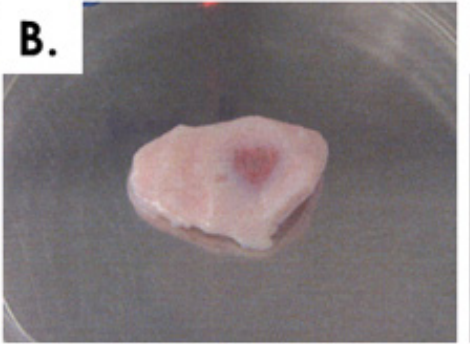

Connective tissue

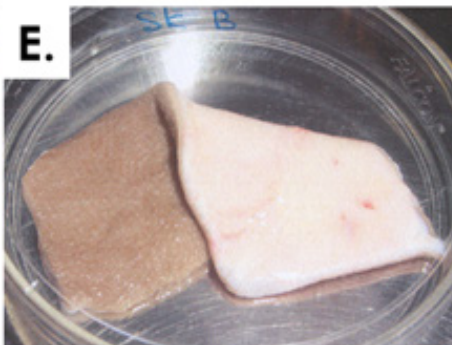

Skin

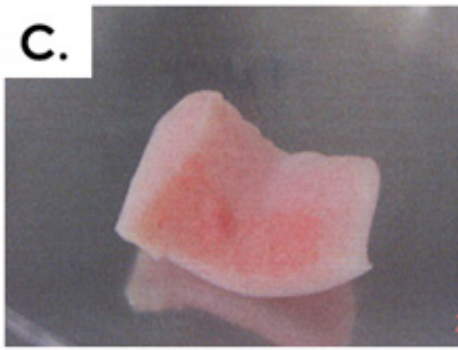

Cartilage

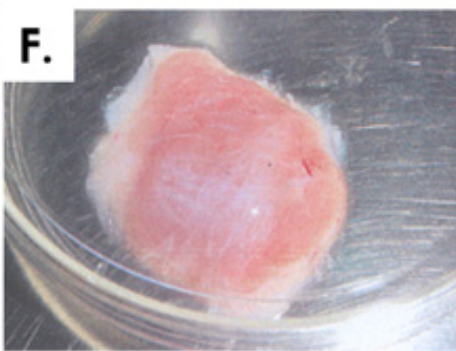

Muscle

Figure 1: Equine fetal tissue fragments isolated during micro-dissection from donation ED002 (11 months gestational age). A) Tendon, superficial digital flexor tendons, mid-metacarpal region. B) Dense connective tissue, diaphragm region. C) Cartilage, cartilage-fetlock joint. D) Bone, trabecular, distal metacarpal bone. E) Skin, abdomen region. F) Muscle, thigh region.

\section{eFPC tiered banking}

For each specific tissue, primary cell types were obtained after culture initiation and subsequently served for PCB establishment. Cell outgrowth from tissue fragments was rapid and emitting cells were fibroblast-like (Figure 2). Depending on the tissue, cultures reached $90 \%$ confluency in the Petri dishes after 7-12 days of incubation. Tiered cell banking of specific eFPC primary cell types was thereafter performed once all PCBs had been established and appropriately stored. For each specific cell types (named after the donor and the organ, e.g. ED001-SK, ED001-Cart for dermal fibroblast progenitors and chondroprogenitors respectively for donor ED001), vials from the PCBs were initiated, cells were culture-expanded and cryopreserved as described in Methods to constitute tiered progeny cell stocks defined as MCBs and WCBs (Figure 3, optimal cell bank sizes). The banking nomenclature and tier depended on the passage number $(\mathrm{Pn})$ characterizing the cell lot and the cell type. Cells in cryovials from the PCB were defined as belonging to P1 in their frozen state, becoming P2 upon reinitiation and subsequent culture-expansion. Each MCB and WCB lot was composed of several dozen vials each containing $2 \times 10^{6}$ to $10^{7}$ viable cells (Figure 3 ). Typical average contents of cell banks were for example 15 vials ED001-Cart P1 (PCB), 70 vials ED001SK P2 (MCB), 230 vials ED002-SK P4 (WCB) or 15 vials ED001-SK P10 (EOPCB). Depending on the cell type, MCB vials contained cells at P2 to P3, while WCB vials contained cells at P4 to P5. To perform experiments, cells could be further culture-expanded to establish tier-2 WBCs at higher passages within the validated in vitro lifespan of the cell types (see hereafter). For each lot destined for animal experimentation, sample vials were selected at the beginning and the end of lot series and were tested for sterility, cell recovery, cell morphology and growth characteristics (population doubling values, PDV and population doubling times, PDT) upon reinitiation. For each lot, a batch record and certificate of analysis were established, yielding lot designation, quantity of vials, date of manufacture, tests performed, specifications, results and release. Non-conforming lots were destroyed and such procedures were documented. Each individual vial was attributed a code and storage locations were updated in a master-log. Logbooks were used to record vial movements, ranging from initial deposit to removal for further banking or experimental purposes. Modifications were dated and signed in the logbook to ensure continued traceability of materials. 


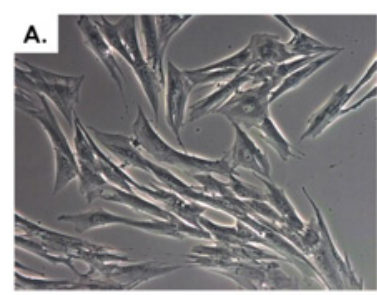

ED001-Ten

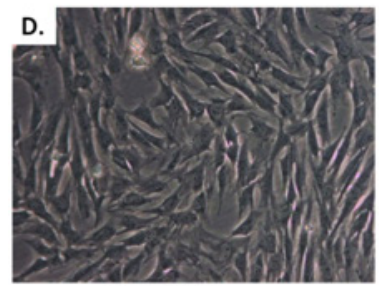

ED001-Bone

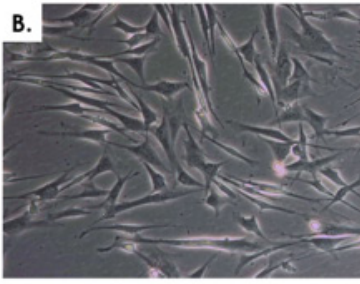

ED001-CT

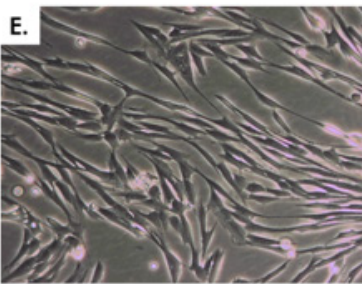

ED001-SK

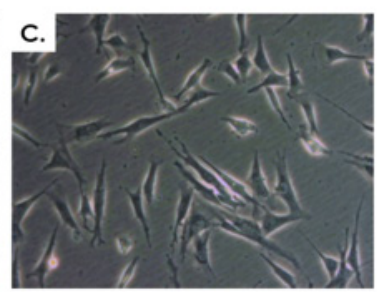

ED001-Cart

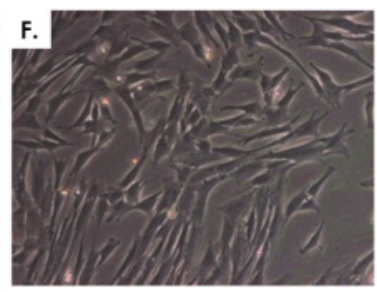

ED001-Mu

Figure 2: Representative imaging of equine primary progenitor cell types (Passage 1) isolated from biopsies of the ED001 donor. A) ED001Ten or equine progenitor tenocytes. B) ED001-CT or equine connective tissue progenitors. C) ED001-Cart or equine chondroprogenitors. D) ED001-Bone or equine osteoprogenitors. E) ED001-SK or equine dermal progenitor fibroblasts. F) ED001-Mu or equine muscle progenitor cells progenitors. Pictures were obtained under 400X optical magnification.

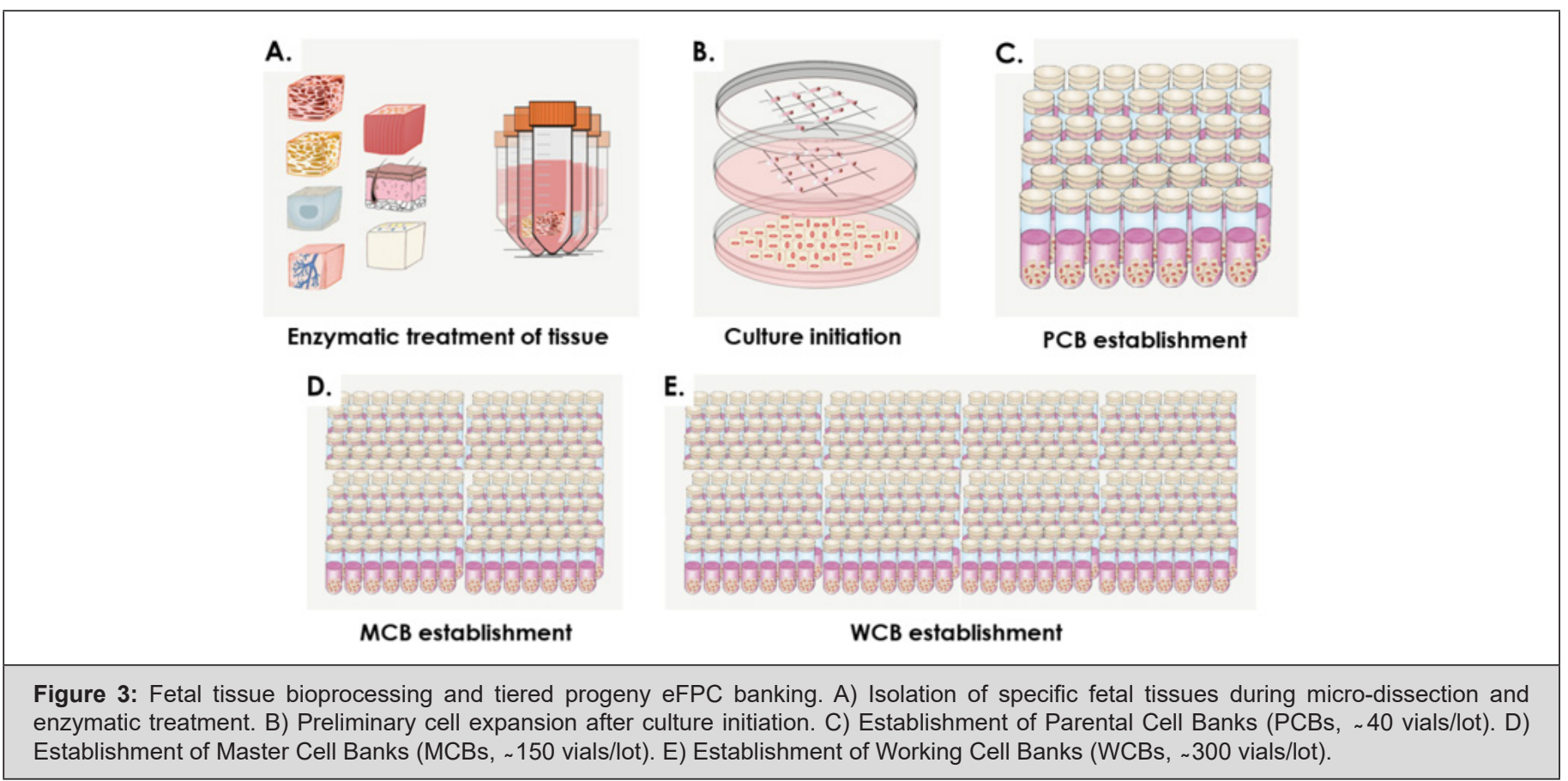

\section{eFPC in vitro characterization}

All considered primary progenitor cell types (derived from skin, muscle, connective tissue, tendon, cartilage and bone), which were established from two different gestational age donations (3 and 11 months) were grown in parallel to establish similarities and differences in cellular growth parameters. Differential characterization of the various primary equine progenitor cell types was performed by microscopic observation (Figure 2) and comparison of phenotypes to other progenitor cells (ovine or human) isolated from the same respective organs. Cell types from both donors consistently displayed rapid growth from original biopsies and subsequently in monolayer cultures. Cell morphology was fibroblastic in nature (spindle-shaped cells, elongated for certain cell types) by consistent throughout passages and characteristic for specific cell types. The different equine cell types of interest were characterized at different passages (P2P8) to obtain growth curves (Figure 4, cells at P4). Cell viability quantification upon initiation, PDVs and PDTs were obtained for each cell type at different passages (Table 3). Growth curves and expansion parameters displayed similarities and differences between the considered cell types and donors (Figure 4 and Table 
3). ED001-Mu, ED001-Ten, ED002-CT and ED002-Mu produced the highest endpoint cell yields at P4, while ED001-CT, ED001Bone, ED002-Cart and ED002-Ten produced the lowest yields in the same conditions (Table 3 , statistically significative differences in endpoint cell yields, $\mathrm{p}<0.05$, Student's t-test). Specificities therefore characterized each cell type and cell behavior in culture, which additionally varied between gestational ages in terms of proliferation kinetics and yields.

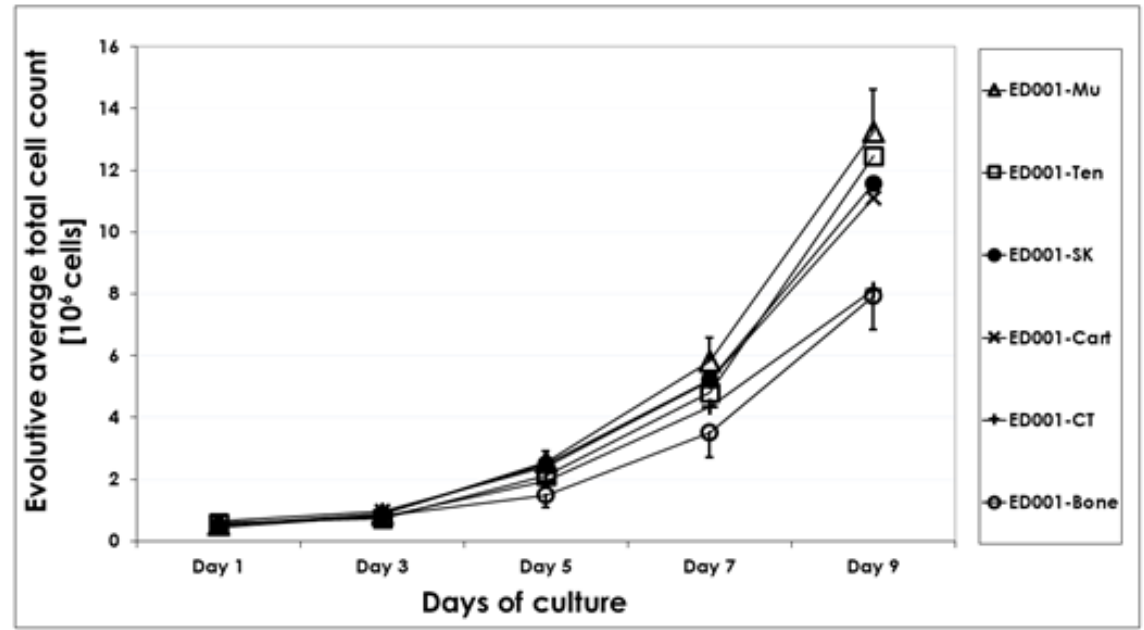

Figure 4: Growth curves representing comparative cell proliferation of eFPC cell types derived from equine fetal donations (skin, muscle, cartilage, bone, connective tissue and tendon biopsies). The average and evolutive total cell counts are presented as a function of time for cultures in T75 flasks. Data is presented for donor ED001 cell types at P4. Associated standard deviations of average counts are presented only for certain cell types as error bars to avoid overcrowding the data plots. Experiments were performed in triplicate and in three experimental repetitions.

Table 3: Characterization of equine progenitor cell types from both organ donations (ED001 and ED002, 3- and 11-months gestational age, respectively). Data report the relative cell viability upon initiation as determined in triplicate by manual enumeration using Trypan Blue exclusion dye. Assorted PDVs and PDTs are based on data obtained for cultures in T75 culture flasks, after nine full days of incubation. Each average value is given for cells at P2 and P8 as obtained during the in vitro lifespan assays. Cell viability data are presented assorted to respective standard deviations.

\begin{tabular}{|c|c|c|c|c|c|c|}
\hline \multirow{2}{*}{ Cell type (original tissue) } & \multicolumn{3}{|c|}{ Passage 2 } & \multicolumn{3}{c|}{ Passage 8 } \\
\cline { 2 - 6 } & $\begin{array}{c}\text { Relative cell } \\
\text { viability [\%] }\end{array}$ & PDV & PDT [h] & $\begin{array}{c}\text { Relative cell } \\
\text { viability [\%] }\end{array}$ & PDV & PDT [h] \\
\hline ED001-SK (dermis) & $98 \pm 2$ & 4.68 & 46.14 & $90 \pm 4$ & 4.36 & 49.55 \\
\hline ED001-Cart (cartilage) & $96 \pm 1$ & 4.62 & 46.73 & $91 \pm 3$ & 4.28 & 50.44 \\
\hline ED001-Ten (tendon) & $94 \pm 2$ & 4.79 & 45.12 & $89 \pm 2$ & 4.54 & 47.62 \\
\hline ED001-Mu (muscle) & $99 \pm 3$ & 4.88 & 44.30 & $93 \pm 3$ & 4.77 & 45.27 \\
\hline ED001-CT (connective tissue) & $97 \pm 3$ & 4.17 & 51.77 & $91 \pm 2$ & 4.00 & 53.94 \\
\hline ED001-Bone (bone) & $93 \pm 2$ & 4.14 & 52.19 & $89 \pm 3$ & 3.92 & 55.08 \\
\hline ED002-SK (dermis) & $97 \pm 2$ & 3.87 & 55.88 & $93 \pm 1$ & 3.65 & 59.22 \\
\hline ED002-Cart (cartilage) & $95 \pm 1$ & 3.76 & 57.45 & $91 \pm 3$ & 3.66 & 59.09 \\
\hline ED002-Ten (tendon) & $95 \pm 4$ & 3.60 & 60.05 & $90 \pm 2$ & 3.45 & 62.70 \\
\hline ED002-Mu (muscle) & $97 \pm 3$ & 4.01 & 53.91 & $92 \pm 5$ & 3.87 & 55.81 \\
\hline ED002-CT (connective tissue) & $95 \pm 4$ & 4.06 & 53.18 & $88 \pm 4$ & 3.89 & 55.47 \\
\hline ED002-Bone (bone) & $91 \pm 2$ & 3.94 & 54.75 & $85 \pm 3$ & 3.74 & 57.69 \\
\hline PDV-Population Doubling Values, PDT-Population Doubling Times. & & & \\
\hline
\end{tabular}

Consistency of cell growth and morphology were confirmed up to at least passage 8 during in vitro lifespan evaluations and following criteria defined under Methods (Table 3). EOPCBs were established at P8 for most cell types. PDV values ranged from 3.45 (ED002-
Ten P8) to 4.88 (ED001-Mu P2) while PDTs ranged from $44.30 \mathrm{~h}$ (ED001-Mu P2) to $62.70 \mathrm{~h}$ (ED002-Ten P8). Table 3 indicates that ED002 cell types presented relatively inferior performances than ED001 in terms of expansion kinetics and cell yields. With regard 
to cell stability during cryopreservation, viable cell recovery and plating efficiency were determined to be $>80-90 \%$ after eight years of storage. PDTs and PDVs obtained by experimental repetition after 8 years of storage were similar to values obtained at the time of equine cell banks establishment (data not shown). The overall stability of eFPCs was confirmed by the relatively high viability of the different progenitor cell types upon initiation, during passage procedures and in cyto-compatibility assays, whereas relative viability results $<85 \%$ were rarely observed (Tables $3 \& 4$ ).

\begin{tabular}{|c|c|c|c|c|c|}
\hline Cell type and passage & $\begin{array}{l}\text { Culture vessel / } \\
\text { Scaffold }\end{array}$ & $\begin{array}{c}\text { Initial cell yield }\left[1^{3}\right. \\
\left.\text { cells } / \mathrm{cm}^{2}\right] \text { Viability } \\
{[\%]}\end{array}$ & $\begin{array}{c}\text { Cell yield } D_{3}\left[10^{3}\right. \\
\left.\text { cells } / \mathrm{cm}^{2}\right] \text { Viability } \\
{[\%]}\end{array}$ & $\begin{array}{c}\text { Cell yield } D_{6}\left[10^{3}\right. \\
\left.\text { cells } / \mathrm{cm}^{2}\right] \text { Viability } \\
{[\%]}\end{array}$ & 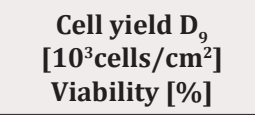 \\
\hline ED001-SK P5 & T75 $\left(\right.$ Nunc $\left.^{\circledast}\right)$ & $\begin{array}{l}2.0 \pm 0.0 \\
98 \pm 2 \%\end{array}$ & $\begin{array}{l}3.9 \pm 0.3 \\
96 \pm 2 \%\end{array}$ & $\begin{array}{c}23.2 \pm 1.9 \\
97 \pm 2 \%\end{array}$ & $\begin{array}{r}51.4 \pm 6.2 \\
96 \pm 3 \%\end{array}$ \\
\hline ED001-Mu P5 & T75 $\left(\right.$ Nunc $\left.^{\circledR}\right)$ & $\begin{array}{l}2.0 \pm 0.0 \\
99 \pm 1 \%\end{array}$ & $\begin{array}{l}3.9 \pm 0.3 \\
98 \pm 1 \%\end{array}$ & $\begin{array}{l}25.0 \pm 2.8 \\
95 \pm 3 \%\end{array}$ & $\begin{array}{c}58.8 \pm 6.6 \\
96 \pm 2 \%\end{array}$ \\
\hline \multirow[t]{2}{*}{ ED001-Ten P5 } & T75 $\left(\right.$ Nunc $\left.^{\circledR}\right)$ & $\begin{array}{l}2.0 \pm 0.0 \\
99 \pm 1 \% \\
\end{array}$ & $\begin{array}{l}2.1 \pm 0.2 \\
93 \pm 4 \% \\
\end{array}$ & $\begin{array}{l}11.6 \pm 2.5 \\
96 \pm 3 \%\end{array}$ & $\begin{array}{r}24.2 \pm 21 \\
97 \pm 2 \% \\
\end{array}$ \\
\hline & & $\begin{array}{l}\text { Initial cell yield [cells/ } \\
\text { mm }^{3} \text { ] Viability [\%] }\end{array}$ & $\begin{array}{l}\text { Cell yield } D_{3} \text { [cells/ } \\
\text { mm }^{3} \text { ] Viability [\%] }\end{array}$ & $\begin{array}{l}\text { Cell yield } D_{6} \text { [cells/ } \\
\text { mm }^{3} \text { ] Viability [\%] }\end{array}$ & $\begin{array}{l}\text { Cell yield } D_{9} \text { [cells/ } \\
\text { mm }^{3} \text { ] Viability [\%] }\end{array}$ \\
\hline $\begin{array}{c}\text { ED001-SK \& } \\
\text { ED001-Mu P5 (1:1) }\end{array}$ & $\begin{array}{l}\text { Tissue Fleece }^{\circledR} \text { (Baxter } \\
\text { AG, equine collagen) }\end{array}$ & $\begin{array}{c}25.0 \pm 0.0 \\
99 \pm 1 \%\end{array}$ & $\begin{array}{c}68.4 \pm 19.8 \\
96 \pm 2 \% \\
\end{array}$ & $\begin{array}{c}123.4 \pm 27.7 \\
92 \pm 2 \%\end{array}$ & $\begin{array}{c}159.3 \pm 32.6 \\
94 \pm 3 \% \\
\end{array}$ \\
\hline ED001-Ten P5 & $\begin{array}{l}\text { Mesolis }^{\mathrm{TM}} \text { (Anteis SA, } \\
\text { reticulated hyaluronic } \\
\text { acid) }\end{array}$ & $\begin{array}{l}20.0 \pm 0.0 \\
97 \pm 2 \%\end{array}$ & $\begin{array}{l}24.1 \pm 8.3 \\
89 \pm 5 \%\end{array}$ & $\begin{array}{l}44.0 \pm 12.9 \\
92 \pm 3 \%\end{array}$ & $\begin{array}{l}76.2 \pm 15.0 \\
95 \pm 3 \%\end{array}$ \\
\hline
\end{tabular}

\section{Cyto-compatibility of eFPCs with collagen and HA constructs}
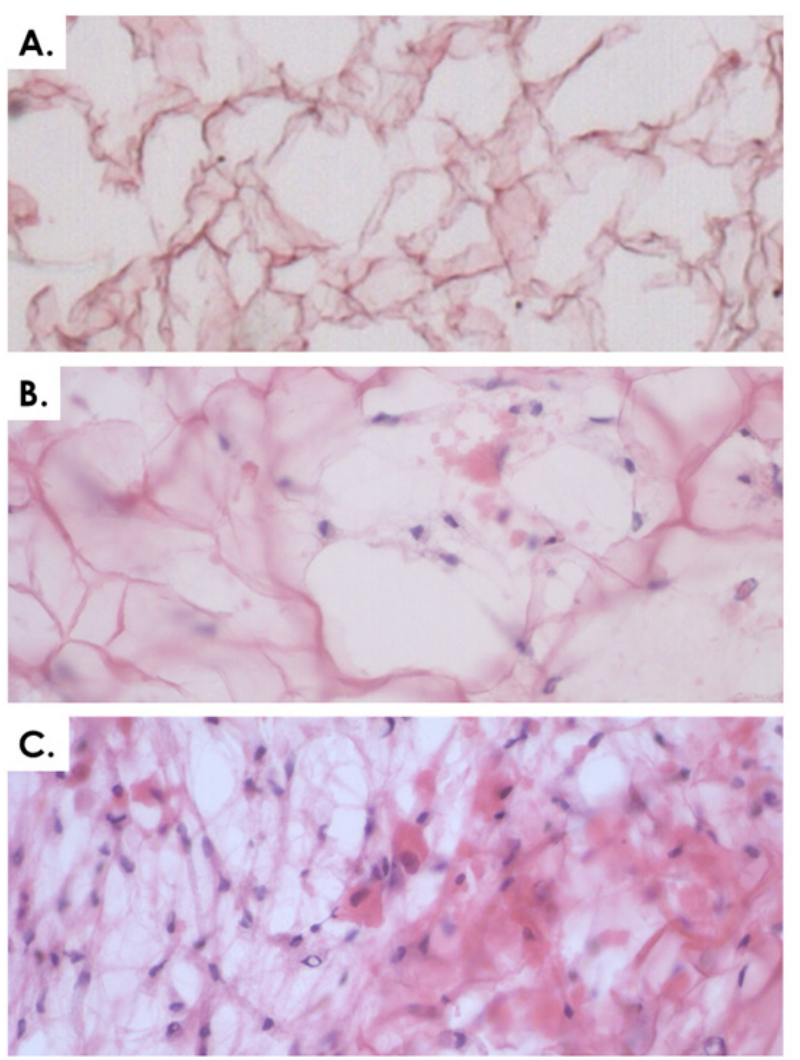

Figure 5: Cyto-compatibility of equine progenitor cells (ED001-SK) with collagen scaffolds. A) Equine Progenitor Biological Bandage without cells (control) after a two-week incubation period. B) Progenitor cells in the collagen scaffold after a two-week incubation period. C) Progenitor cells in the collagen scaffold after a four-week incubation period. Data was obtained using $20 \mu \mathrm{m}$ sections stained with HE, imaged under $400 \mathrm{X}$ optical magnification. 
Specific cell types were selected based on optimal growth kinetics (Figure 4 \& Table 3). Cyto-compatibility of ED001-SK and ED001-Mu progenitor cells with equine collagen sheets was assessed. Progenitor cells integrated in the scaffolds for periods of four days to one month did not show any differences in morphology. No biodegradation or significant construct thickness changes were observed over the one-month period, as the two mm dimension was conserved from the matrix in its dry state. After approximately three weeks of culture, slight shrinking of the planar size of the constructs could be measured $(\sim 0.5 \mathrm{~cm})$ and was most likely due to high cell concentrations and ensuing constriction forces. Histology from serial samples at one, two and four weeks was accomplished and HE staining showed high cellular integration throughout the entire collagen matrix and not only on the surface. Cell populations were evenly distributed after two weeks of culture already (Figure 5). The three-dimensional environment sustained significant cellular proliferation during incubation (Table 4). Indeed, the total cell count evolved from 25 cells $/ \mathrm{mm}^{3}$ ( $99 \pm 1 \%$ viability) at the time of seeding to $159.3 \pm 32.6$ cells $/ \mathrm{mm}^{3}$ ( $94 \pm 3 \%$ viability) after nine days of incubation.
Cyto-compatibility of ED001-Ten progenitor cells with an HA hydrogel was assessed by monitoring cell survival and cell growth characteristics within the hydrogel. The cell type was selected based on optimal growth kinetics (Figure 4 \& Table 3). In the assay multi-well plates, cells were observed to rapidly migrate throughout the gel and easily attach to the cell culture plate surface, as indicated by direct optical microscopy (Figure 6). Cell growth within the hydrogel could be monitored not only visually but also quantitatively by removing samples each day and counting total cell numbers (Figure 6, Table 4). Cell counts were plotted in function of the number of days in culture and portrayed increasing cell growth throughout the culture period (Table 4). Indeed, the total cell count evolved from 20 cells $/ \mathrm{mm}^{3}$ ( $97 \pm 2 \%$ viability) at the time of seeding to $76.2 \pm 15.0$ cells $/ \mathrm{mm}^{3}$ ( $95 \pm 3 \%$ viability) after nine days of incubation. Healthy cell growth was observed based on morphological evaluation and evolutive cell counts. Interestingly, once fetal equine tendon cells were confluent in mono-layer, they rapidly grew in three dimension (3D) throughout the hydrogel (Figure 6D).
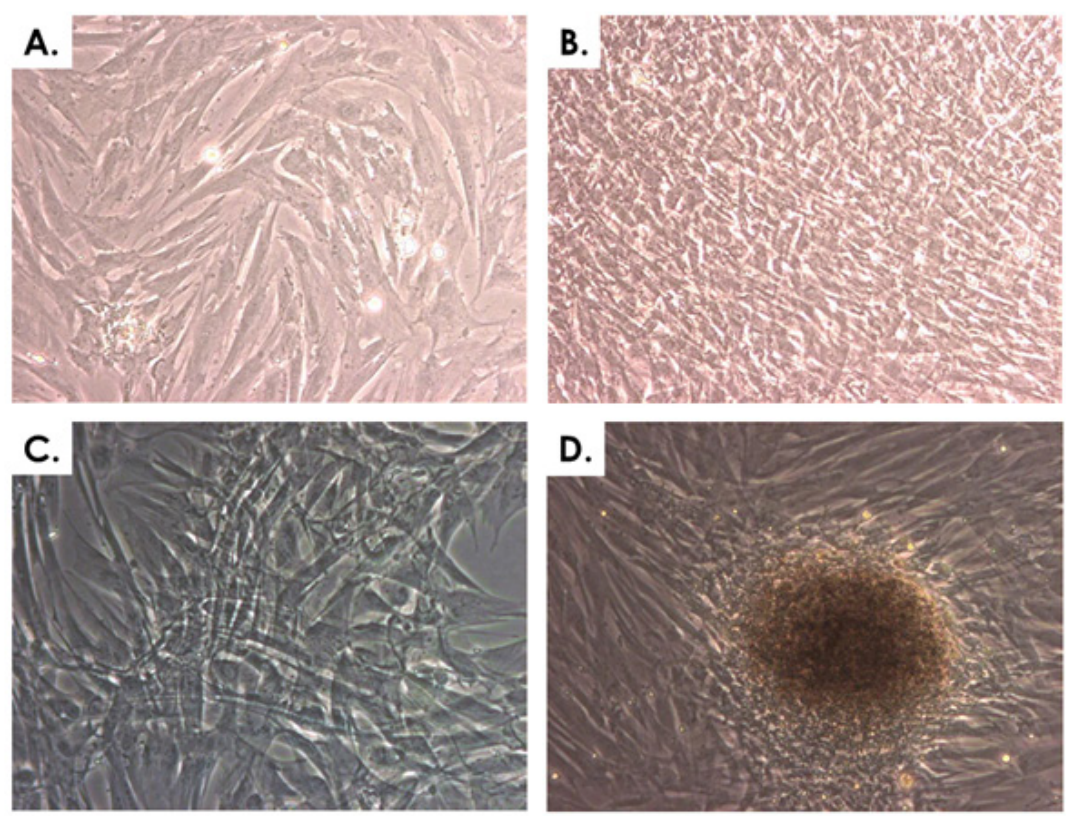

Figure 6: Cyto-compatibility of equine progenitor cells (ED001-Ten, P5) with hyaluronic acid hydrogels. A) Cells growing in standard culture conditions. B) Cells after a 20-day culture period having attained over-confluency in standard culture conditions. C) Cells growing in the hydrogel after a one-week incubation period. D) Cells forming $3 \mathrm{D}$ structures in the hydrogel after a two-week incubation period. Representative imaging was performed under $400 \mathrm{X}$ optical magnification.

\section{Case reports of ePBB application}

Primary banked eFPCs were used for the development of ePBBs destined for application in hippiatric medicine following severe and complex wounds. The overall objective of the general approach was to tentatively extrapolate potent results of healing rate stimulation obtained in human medicine with human progenitor cells to the veterinary setting. The specific objective of the present collection of cases was to preliminarily assess the safety of application of ePBBs in equine patients and to verify absence of immunogenicity or rejection and absence of induced wound healing delay. The first case consisted in treatment of a severe distal limb wound (knee injury) with deep tissue exposition. Treatment occurred 24 hours post-injury. As for all patients, pre-operative sedation medication was xylazine $(0.6-0.7 \mathrm{mg} / \mathrm{kg}$ body weight, Streuli 
Pharma AG, Switzerland). Induction of anesthesia was performed with Narketan ${ }^{\circledR} 10$ (ketamine, $2 \mathrm{mg} / \mathrm{kg}$ body weight, Vetoquinol AG, Switzerland) and climazolam ( $0.2 \mathrm{mg} / \mathrm{kg}$ body weight, Dr. E. Graeub AG, Switzerland). The patient was intubated and maintained in a surgical plane of anesthesia by inhalation of halothane $3 \%$, Fluothane $^{\infty}$, AstraZeneca, Germany) in a supine position on an operating table (Figure 7). Under appropriate controlled sedation and anesthesia, the region around the wound was shaved, the wound was cleaned and thoroughly rinsed with normal saline, disinfected with hydrogen peroxide and rinsed again. Three full ePBB constructs were made available after one week of incubation. Constructs had been prescribed and ordered as a veterinary magistral preparation. ePBBs were placed directly and tightly into the lesion (Figure 8A-B) and over-layered with petroleum jelly coated gauze. Cotton gauze bandages protected the constructs and the primary gauze, while stitches helped to stabilize the bandage. The surgical site was then covered in a routine manner using Polysorb ${ }^{\star}$ (Tyco Healthcare, UK) staples and sutures (Figure 8C). After end of surgery and reanimation, the patient was kept immobilized in her box stall for three days after which she was allowed to move freely on the paddock. Three days after the intervention, bandages were removed and replaced with standard wound coverages before return of the patient to the paddock. Evolutive evaluation of the wound was realized by subjective macroscopic examination by an experienced veterinarian. Granulation tissue covered the surface of the wound and the deep tissue exposure was resolved, as the deepest portion of the wound remained filled with the remains of the ePBBs which fused with the adjacent repairing tissues (Figure 8D). Borders of the wound were well defined and in the process of reepithelialization. Standard wound care continued with regular bandage exchanges. Full mobility was restored after the threeday immobilization and the wound was considered closed after a treatment period of two weeks. Based on practical veterinary experience, similar clinical presentations $(3 \mathrm{~cm}$ wide $\times 2 \mathrm{~cm}$ deep wounds) would normally heal in approximately one month and impose strict mobility restriction. In particular, the resolution of the deep tissue exposure would have necessitated more time and the outcome generally comprises permanent volumetric loss at the site of injury.

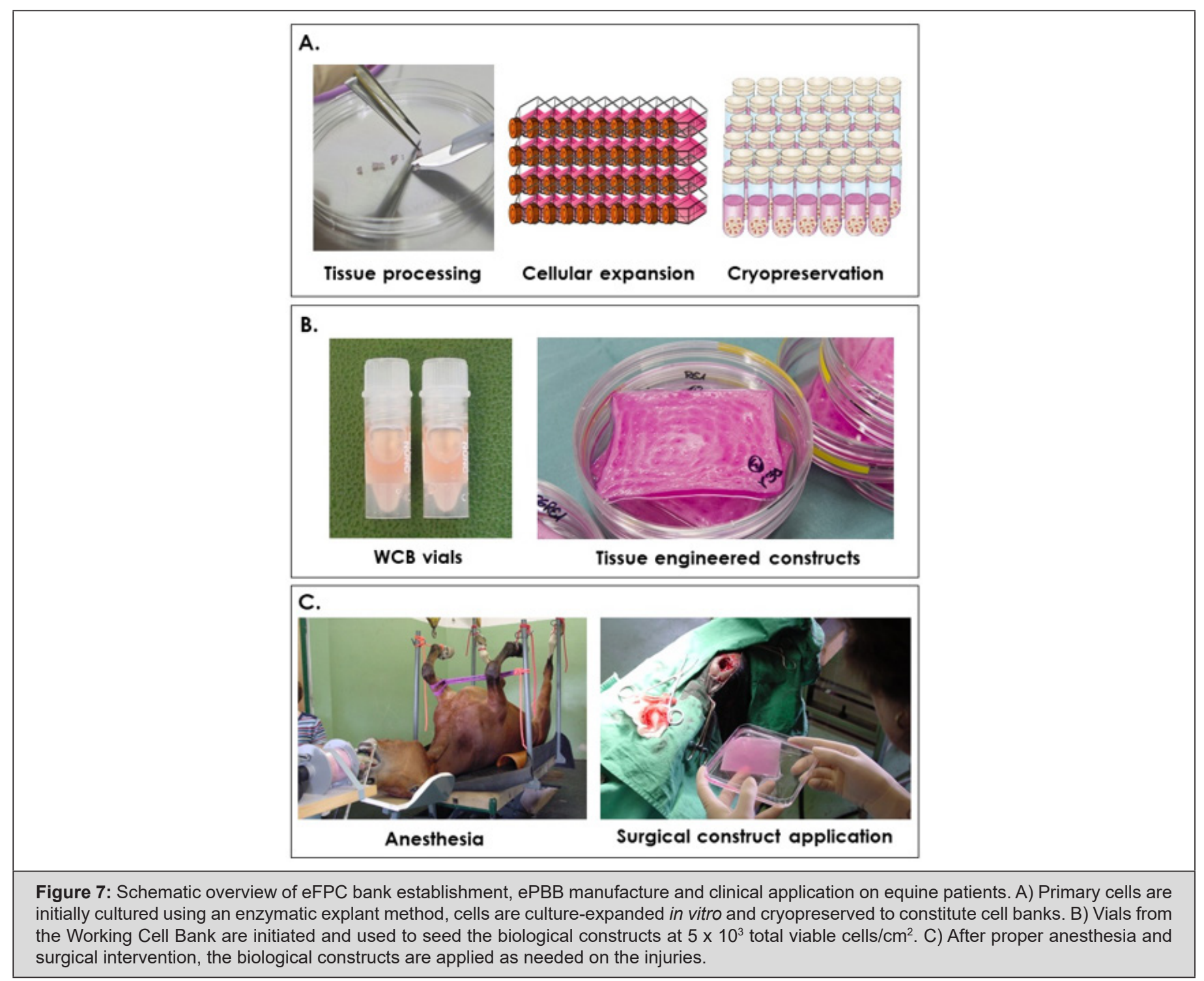


The second case consisted in a mandibular necrotic and transfixing wound (Figure 8E). Treatment occurred 72 hours after the wound created an opening in the mandibular wall tissue. Under appropriate anesthesia as described hereabove, the incriminated tooth was removed and the resulting mandibular space was caped using Technovit ${ }^{\circledast}$ 6091/easy (Heraeus Kulzer \& Co., Germany). The injury canal was cleaned and cleared of any excess granulation tissue using sterile surgical scissors. The wound was then thoroughly rinsed with sterile normal saline containing gentamycin $(0.1 \mathrm{mg} / \mathrm{mL}$, Veterinaria AG, Switzerland), disinfected with hydrogen peroxide and rinsed again before 2.5 full ePBBs which had been incubated for one week were inserted to fill the volumetric defect (Figure 8F). The entire wound bed was overlaid with Jelonet ${ }^{\mathrm{TM}}$ (Smith and Nephew Medical, UK), covered with gauze and then sutured into place (Figure 8G). After reanimation, the patient was kept in his box stall for three days after which he was allowed to move freely on the paddock. The bandages and staples were removed six days later (nine days post-surgery, Figure $8 \mathrm{H}$ ). Slight superficial tissue granulation was observed on an otherwise healthy surface. ePBB constructs appeared to have integrated the repairing tissues and undergone resorption, being replaced with repairing tissue. The internal side of the wounded area was exempt of inflammation four days post-intervention and normal nutritive intake could resume 48 hours after surgery. Aside from mouth rinsing with antibiotic solutions, the wound required no further care. Two additional equine cases (4-year-old and 5-year-old Franche-Montagne male horses) were treated with the same therapeutic indication (mandibular necrosis following tooth abscess) and treatment protocol, with similar evolutions and comparable total wound closure (data not shown).

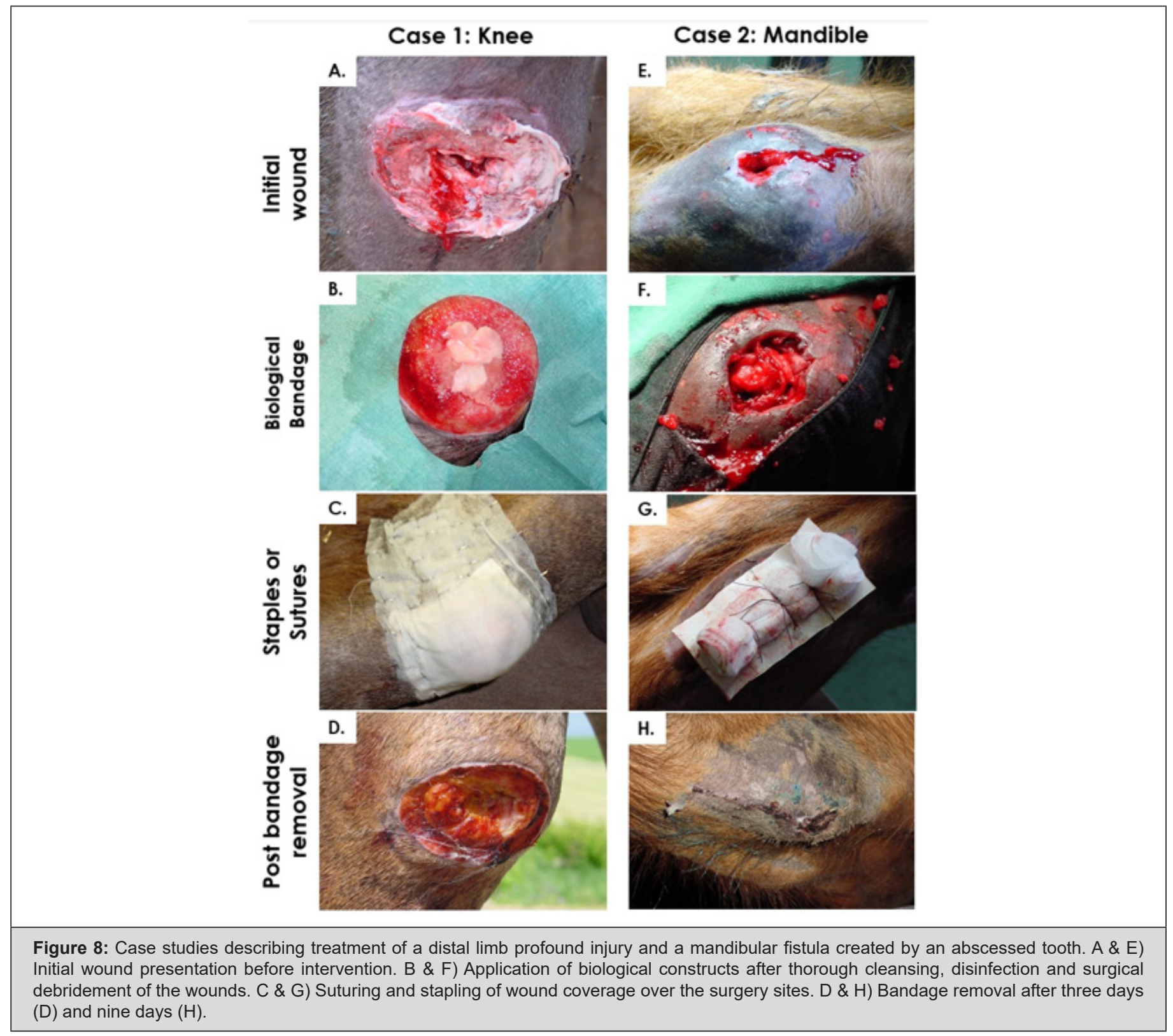




\section{Discussion}

\section{Wound healing and treatment options in hippiatric medicine}

Equine distal limb injuries are notably characterized by feeble intrinsic regeneration capacities and slow wound healing rates. High adjacent skin tension, relative absence of underlying soft tissues, low propension for wound contraction and limited epithelialization render healing of such equine injuries arduous [16]. Trauma induced ischemia, constitutive hypoxia and inflammation contribute negatively to physiological repair mechanisms by promoting formation of EGT [18]. Equine models of wound healing best approach human physiological processes and can potentially be used in large animal studies, as both species strongly depend on physiological modulation of endogenous tissues toward reepithelialization. Excessive production of granulation tissue is common to both horses and humans, being defined by formation of proud flesh or keloids (dysplastic newly formed connective tissue and vasculature), respectively, which illustrate the relevance of equine models for translational development of human cutaneous repair products $[13,16]$.

Wound care options within standard veterinary practice are similar to classic human medicine practices, with specificities for application on animal wounds, given the particular aspects of equine tissue healing phases $[1,4,5]$. Current or standard wound dressing and care options (non-biological) for horses are listed and characterized in Table 2. Rising incidence of acute and chronic diseases and relative importance of the horse as a workforce or companion have prompted the development of novel therapeutic products dedicated for veterinary use, often conceptually derived from products destined for human application, in line again with the One Health Initiative [13-18]. Preliminary investigations of bioengineered construct therapeutic potential for treating equine cutaneous affections yielded controversial results, in particular with products such as bovine collagen porous membranes, hydro soluble yeast extracts or derivatives of porcine intestinal mucosa (VetBioSISt, ${ }^{\circledR}$ Smiths Medical-SurgiVet ${ }^{ø,}$, USA) [1,6,7]. Physical and biochemical therapeutic options have also been considered, with variable outcomes $[67,68]$. The use of equine amnion or amniotic fluid has yielded encouraging results, as comparison of the therapies to non-adherent bandages indicated a shortening of wound healing periods. Amniotic fluid contains growth factors, angiogenic factors and possesses a bactericide action [8]. Despite advances in cutaneous wound care and due to the exposure of horses to extensive trauma to the limbs in particular, more advanced tissue regeneration strategies are required for treatment of lesions to muscle tissue, tendon, cartilage and bone, which often present volumetric losses and require either tissue transplants or advanced wound coverage. This therapeutic niche and high demand have spawned the development of cell therapies and bioengineering of novel combination products destined for hippiatric medicine in parallel to or as part of therapeutic developments in human medicine.

\section{Fetal progenitor cell sources for regenerative medicine}

Cell therapy and tissue engineering developments are producing novel approaches with remarkable induction of biological functions and clinical effects, whereas therapeutic cell choice and processing thereof is of utmost importance. Fetal tissues have been invaluable investigational tools in embryology, developmental anatomy and physiology [31,46,58]. Fetal cells additionally benefit from extensive industrial use and hindsight in biotechnology and pharmaceutical fields, being key substrates for production of viral vaccines for diseases such as polio and rabies [41]. Associated tissues such as placenta, amnion, amniotic fluid, umbilical cord and cells derived thereof have also been investigated for the development of new therapeutic products $[6,8,31,33,69,70]$. Effective development and industrial transposition of cell therapy manufacture are highly dependent on the selected cell source, processing thereof and resulting intrinsic characteristics. In view of tangible widespread application, tissue engineering processes must meet stringent criteria such as safety, consistency, rapidity and reliability in order to remain effective and cost-effective $[46,53,69]$. Regulatory frameworks and classifications should also be taken into account in early phases of therapy or product development [71]. Table 1 lists and characterizes major cell sources of interest (including autologous, allogeneic and xenogeneic) for development of therapeutic strategies and products. Primary fetal progenitor cells isolated following standardized protocols possess numerous intrinsic technological advantages making them optimally suitable for regenerative medicine applications. Low technical culture requirements (simple and standardizable industrial processes), high proliferation rates and extensive expansion potential (i.e. > 10 in vitro passages with high PDVs) enable robust and tangible establishment of large consistent and characterized cell banks. Such cell stocks can potentially be relatively much larger than stem cell banks for example, whereas higher seeding densities ( $>10^{4}$ viable cells $/ \mathrm{cm}^{2}$ ) are used for shorter in vitro lifespans (e.g. 3-4 passages). Valuable therapeutic attributes such as high resistance to oxidative stress, stable defined and differentiated phenotypes, low potential towards immunogenicity or tumorigenicity and optimal cyto and biocompatibility reinforce the interest in progenitor cell banks for allogeneic regenerative medicine [45,53,57].

As was previously demonstrated in human translational medicine, simultaneous isolation of various fetal progenitor cell types from one organ donation enable highly efficient research and therapeutic development in all major aspects of musculoskeletal cell therapies $[45,53,56,59,60,63]$. Such knowledge and experience were extrapolated to veterinary therapeutic research, as immune privilege of progenitor cells potentially allows for safe xenogeneic 
transplantation, while use of allogeneic animal cells and veterinary applications may benefit from relatively alleviated regulatory requirements $[54,62,65,66]$. Restricted need for repetition of cell isolation procedures yielded by techniques described herein largely benefit temporal and economic factors of therapeutic supply chains. Avoidance of multiple organ donations and careful selection of donor parameters exclude inter-individual variability and the need for manipulation of cell types with regard to phenotypic identity or lineage commitment. Consistent establishment of safe and stable progeny cell banks is possible with minimal processing. Further optimization of cell delivery methods will allow for optimization of manufacturing, storage and distribution logistics, with abolition of the dependency to cryopreservation and ultra-low temperature maintenance for biological materials. Such burdens can be alleviated by specific further processing of cellular materials using existing technologies such as freeze-drying, while stably retaining the intrinsic therapeutic potential of viable and integral progenitor cells.

\section{Cell therapies for hippiatric medicine}

Equine cell therapies have been thoroughly investigated as of late for potential veterinary applications. Notably, bone marrow and adipose stem cells have been investigated regarding their chondrogenic potential. Being aspecific in terms of phenotype, such cell types require many growth and differentiation factors, complicating manufacturing processes and negatively impacting consistency thereof $[3,12]$. Human amniotic fluid yields both fetal cells and stem cells, representing alternative potential sources, yet consistent isolation and large-scale cell banking of latter cell types remains treacherous [31]. In this study, successful development of equine fetal cell banks from various musculoskeletal tissues of interest for bioengineering purposes were described. Rationale for establishing equine fetal cell banks and evaluating their regenerative stimulation potential was the local extensive preliminary experience and hindsight in human wound care using banked progenitor cells of both human and ovine origin, with single therapeutic cell types and combinations thereof $[43,48,66]$. Indeed, preliminary assessments of equine progenitor cell types had been made comparatively with human progenitor cell banks derived from organ donations following highly similar bio-processing and banking frameworks and protocols. eFPCs therefore appeared as optimal candidates for investigation of potential therapeutic veterinary applications.

Cell delivery is a paramount aspect of all cell therapies, as the optimal scaffold is necessary for the deployment of full therapeutic effects of the biological materials. Collagen is a popular scaffold for cell therapies in general as it is constitutively present in animal organisms as a component of the extracellular matrix (ECM) and interacts in all phases of cutaneous wound healing (inflammation, ECM remodeling, contraction and epithelialization) with the effectors of tissue repair. Bioresorbable hemostatic collagen sponges obtained by lyophilization and gamma radiation sterilization are commercially available as medical devices, as well as combination products falling under regulatory classification of combined Advanced Therapy Medicinal Products (cATMP, e.g. Apligraf ${ }^{\star}$, Organogenesis, USA, OrCel ${ }^{\circledR}$, Ortec, USA) [23,42]. The latter yield neonatal fibroblasts and keratinocytes, which are involved in ECM production and paracrine modulation of wound environments during the healing process. Such regulatory and stimulation roles are the defined mechanisms of action for various marketed tissue engineering products (TEPs) [22]. In a similar fashion, ePBBs were engineered as cutaneous substrates intended to favor wound healing by modulation of tissue granulation and stimulate onset of epithelialization.

\section{Cell banking of eFPCs}

Extensive and consistent cell banks were established from fetal equine tissues (skin, muscle, cartilage, tendon, connective tissue and bone) by growing and expanding various musculoskeletal cell types in optimized and standard conditions. Full PCBs could be established rapidly ( $<3$ weeks for all considered cell types) and allowed for subsequent establishment of consistent MCBs and WCBs for experimental and clinical uses. Results indicated that cell growth from donor ED001 (three months gestational age) was more rapid that of donor ED002 (11 months gestational age) for all considered cell types. Such data supports the use of lower gestational age donations for cell banking, while the optimal age remains to be determined by comparative evaluation. The tiered banking system allowed for pragmatic use of the cellular materials. Indeed, extensive expansion capabilities and high stability allowed for experimental use of cells at passages between six and nine depending on the cell type, which theoretically allows for millions of therapeutic constructs to be manufactured using a dedicated cell bank derived from one organ donation. Indeed, despite the small amount of procured tissue at the time of donation, biotechnological processing and tiered cell banking allow for near indefinite propagation of the biological material within adequate banking strategies, consistently retaining initial cellular physiological properties and therapeutic attributes.

Manufacture of WCBs at defined passages for optimal therapeutic effects allow for generation of off-the-freezer allogeneic material sources for cell therapies. Initiation of cryopreserved WCB vials and conjugation of progenitor cells with adequate bioengineered scaffolds or delivery systems allow for prompt generation of advanced wound coverage and tissue reconstruction solutions. While skin and muscle-derived equine progenitor cells have been the main focus of the present study at a translational level, other musculoskeletal cell types such as bone, cartilage, connective tissue and tendon have presented interesting characteristics in vitro. Such cell types should be further investigated for their potential tissue 
engineering applications to repair or replace soft tissue, muscle, cartilage, tendon and bone in parallel to human progenitor cells $[47,51,54,59,60,65]$. Further optimization of cell culture protocols (e.g. hypoxic culture conditions, dynamic culture settings, induction of tissue-specific ECM production) may better mimic the native environment of specific cell types and potentially increase or stimulate the therapeutic supplementation or mediation operated by therapeutic cells [16].

\section{eFPC banks safety testing}

Safety testing of the considered biological materials did not reveal any trace of contamination during culture (sterility of growth medium), nor the presence of mycoplasma in the material constituting the equine cell banks. Presence of equine prions was not investigated, due to the low rate of animal contamination and unavailability of equine-reacting specific antibodies. For safety testing of equine primary fetal progenitor cell types in general, not only can the mother-horse be tested to ensure seronegativity for communicable diseases, but each equine cell bank lot may easily be tested with regard to possible presence of bacterial, fungal and viral adventitious agents. Further regulatory-required testing in GMP (Good Manufacturing Practices) manufacturing settings for clinical use could include identity testing (to assure no cross-contamination upon manipulation of cells), mycoplasma absence and sterility testing (on a routine basis) or in vitro and in vivo adventitious agent detection (determined by regional viral contamination possibilities).

Additional cell bank testing should then include absence verification for contaminants from contact process consumables, and raw materials e.g. bovine viruses from FBS or porcine viruses from trypsin-EDTA. However, use of GMP-certified batches of serum and trypsin that have been previously tested and gamma-irradiated would limit the risk within cell bank production. Optimization and standardization are key concepts in any translational workflows and manufacturing processes, whereas progenitor cells adapt exceptionally well to the specificities of therapeutic product development pathways. Such advantages enable effective safety testing to be performed on homogenous and consistent production lots, ensuring optimal safety of all liberated starting materials for biologic product development.

\section{eFPC characterization}

The overall goal of characterizing biological starting materials is the assurance of working with adequate, effective, consistent, traceable and safe substrates. Based on extensive experience with handling and banking fetal progenitor cells from different tissues (human and ovine origins), microscopic differential phenotype characterization was possible with eFPC cultures, isolated from well-defined original tissue fragments. Culture growth kinetics as well as in vitro life spans and cyto-compatibility parameters were assessed for eFPCs for different donors. In addition, preliminary safety of eFPC sources was established throughout equine cell bank safety assessment and limited in vivo clinical applications. However, in view of optimization and eventual transposition to GMP manufacturing and product development, further insights and standardized quantifiable parameters need to be established and evaluated with regard to cell population identity, purity and potency. Similar challenges exist when working with human progenitor cells, whereas extensive characterization of the biological starting material is far from that of small molecule drugs or therapeutic biologics. Both domains (human or equine progenitor cell banking) may be similarly supplemented in respective manufacturing workflows by identity, purity and potency assays, which can fit both mechanism of action elucidation and quality assurance requirements.

With regard to identity, eFPCs are similar to human progenitors and may be characterized by cell surface maker profiling using specific antibodies (e.g. for human cell types, CD13, CD14, CD26, CD29, CD34, CD44, CD45, CD49a, CD54, CD73, CD90, CD105, CD106, CD146, CD166, HLA-ABC, HLA-DPQR) [59,60]. Such investigations may be conducted using flow cytometry assays or immunocytochemical staining assays. A clear advantage of flow cytometry is that population purity may be simultaneously assessed. Evolution of cell population identity and purity may be assessed using flow cytometry or karyotyping assays performed on materials at various stages of the in vitro lifespan or various time points of cryopreservation. Potency of progenitor cells differs categorically from that of stem cells, which may be easily demonstrated with differentiation assays verifying phenotypic stability (multilineage differentiation assays, 2D/3D adipogenic, osteogenic and chondrogenic induction assays). Additional parameters which may be used to characterize eFPCs in terms of consistency comprise evaluation of evolutive total protein contents, specific gene or total ribonucleic acid (RNA) expression by PCR $[53,59]$. Functional assays are in addition necessary in order for therapeutic proof-of-concepts to be established, in particular for compliance with regulatory requirements. Therefore, progenitor cell therapies may be investigated in many ways in terms of function, including but not limited to assays for stimulation of adequate target cell proliferation, migration, metabolic activity or survival by therapeutic cells or modulation of endogenous ECM or tissue parameters.

\section{Cyto-compatibility of eFPCs}

Both collagen sponges and HA had been previously investigated for delivery of human dermal progenitor fibroblasts, progenitor myocytes and progenitor tenocytes with excellent results with regard to cyto-compatibility and biocompatibility $[43,54,60,65]$. In the particular case of $\mathrm{HA}$, despite the absence of culture medium or growth supplement, cell survival was demonstrated for up to three days of $4^{\circ} \mathrm{C}$ conservation with retention of optimal rheological properties in view of clinical delivery with comparable commercial 
preparations [61]. Based on results obtained with equine progenitor tenocytes, it appears beneficial to maintain incubation of engineered products in order to allow for better cell survival and integration, as ED001-Ten cells continued to proliferate in the hydrogel for up to four weeks in the present study parameters (Table 4).

For the preparation of ePBBs for the equine patients, an empiric combination of cell types was investigated for ePBBs in the particular context of volumetric loss injury, whereas multiple and complementary tissue stimulation properties were required. The cell types (ED001-SK and ED001-Mu) were selected based on optimal growth kinetics (Figure 4 \& Table 3). Based on excellent cyto-compatibility results with eFPCs and construct physicochemical properties, collagen constructs seeded with equine progenitor cells meet preliminary requirements for adequate cutaneous wound coverage or tissue reconstruction product development. With regard to HA hydrogel investigation for equine progenitor tenocyte delivery, the cell type (ED001-Ten) was selected based on optimal growth kinetics (Figure 4 \& Table 3) and the high incidence of tendon injuries in equine patients. Based on observed cyto-compatibility and HA construct properties, hydrogels yielding equine progenitor cells meet preliminary requirements for development of appropriate injectable cell therapy options for damaged equine tissues.

Overall, both investigated scaffold options proved to be cytocompatibility with the eFPCs of interest and had been characterized as biocompatible during respective evaluations for CE marking. These two systems provide delivery options for external and internal wounds to be treated with equine progenitor cells, yet further developments are required in order to identify cyto-compatible and biocompatible matrices suitable for cell delivery and reconstruction of musculoskeletal defects impacting tendon, cartilage and bone. Hydrogels for human progenitor tenocyte delivery have been previously described [61]. For cartilage cell therapies, polymeric structures based on polyethylene glycol (PEG), chitosan, albumin or hyaluronan have been investigated for injectable applications yielding adhesive, chondrogenic and mitogenic properties [64]. Bone cell therapies using progenitor cells have been evaluated with poly(L-lactic acid)/tricalcium phosphate scaffolds with encouraging results $[52,63]$. Data gathered around the behavior of eFPCs in the collagen biological matrices of interest are similar to results obtained with human progenitor cells in the same polymeric scaffolds, which are being investigated in clinical trials in Switzerland (CHUV, Bru_PBB Priority Project) and Asia (Taiwan and Japan, trial ID numbers NCT03624023 and NCT02737748) for donor site wounds and diabetic ulcers [43,47,48,50,57,58].

\section{Hippiatric case reports of ePBB application}

In all clinical cases, no biopsies were taken to evaluate eFPC persistence during the wound healing phase. Furthermore, limited and preliminary conclusions could be drawn from the considered cases, as no controls could be used to comparatively assess the influence of ePBBs against standards of care. However, similarities could be observed between the use of ePBBs in equine subjects and application of human PBBs in burn patient populations. Indeed, while being unquantified, some inflammation reduction and apparent stimulation of tissue repair was observed. Absence of immunogenicity and tumorigenicity was confirmed, by patient examination at the time of wound closure and one year later, respectively. Effects of ePBB applications were subjectively evaluated by attending veterinarians as safe and positive towards tissue repair and wound healing.

The different advantages of optimized progenitor cell banking allow for manufacture of bioengineered cell therapy constructs at relatively low direct costs, as reported for human PBBs [26]. Given the apparent beneficial effect of ePBBs on equine wound healing, which needs confirmation on a larger patient group in a controlled comparative study, the drastic economic consequences brought down by severe injuries in highly valuable veterinary patients (e.g. race horses or camels) might be alleviated by application of such novel therapies. In addition, due to the high levels of similarity between human and equine cutaneous wound healing and the documented immune privilege characterizing primary progenitor cells, equine models appear as optimal for large animal studies during development of such human wound healing solutions. In parallel and as demonstrated in the present work, the use of investigational therapies as veterinary magistral preparations might benefit numerous equine patients otherwise destined for euthanasia, while gathering extensive preclinical safety data, in a relatively straightforward regulatory framework. As evidenced during translational work in human clinical cases, optimal therapeutic gains provided by highly-specialized medicine and novel products may only deploy their full beneficial effects through close inter-professional collaboration between research, regulatory, paramedical and medical personel, which all gravitate around and support the patient in her/his journey towards recovery and health restoration.

\section{Overall assessment of eFPCs}

Based on the exposed technical data and gathered experience around progenitor cells and eFPCs in particular, major important aspects and specificities confirm the suitability of such primary cell types for large-scale cell banking and bioengineered product assembly. Indeed, due to robustness and consistency of cellular characteristics throughout processing, progenitor cells optimally adapt to the stringent requirements of GMP manufacturing workflows with regard to technical parameters and safety screening. Both cell delivery scaffolds (collagen and HA) were confirmed to be well adapted for conjugation with eFPCs based on cyto-compatibility parameters. Such data align with prior art around the use of human progenitor cells in PBBs, whereas standardized cellular construct preparation (scaffold size and cell 
seeding density) allowed for robustness of experimental assays and sparing use of biological materials. Specifically, while using tiered cell banking and construct incubation periods before clinical application, the required quantity of therapeutic cells is relatively inferior to those of injectable cell-based products, which can contain several $10^{9}$ cells/dose. The choice of cell seeding density had been derived from clinical experience around human PBBs, where live therapeutic cell yields had been optimized and validated in our Burn Center [43,46,47,49]. However and although the observed efficacy was classified as satisfactory in the present case studies, therapeutic cell doses seeded and obtained after construct incubation might benefit from further optimization with regard to specific injury classification, location and topology. In addition, simple manufacture and optimal physico-chemical properties of collagen scaffolds (moldability, capacity for bio-resorption and cell adherence) resulted in optimal construct colonization, viable integration and proliferation of seeded eFPCs.

Optimal cell sources, standardized processing thereof and tangible delivery methods and tools are paramount for cost-effective transposable development of investigational therapeutic products. Nonetheless, the choice of biological starting material often proves to be the limiting factor for effective product development. Significant intrinsic parameters of progenitor cells have been extensively studied using human cell types and comprise high stability and consistency, safe and extensive cell banking suitability, immune privilege, resistance to oxidative stress, potential for interplay with host ECM and potent therapeutic effects exerted by paracrine modulation.

Xenogeneic histocompatibility and avoidance of immune system effectors by human progenitors was demonstrated in immune-competent murine models $[54,62,65]$. By analogy to human cell types, the existence of similar advantages in equine progenitor cell populations was to be investigated. Preliminary results relative to cell banking and safety of clinical application support the existence of strong parallels between human and equine progenitor cell types. Such attributes may be of interest in a regulatory-driven approach toward cATMP (conjugate of live cells and a medical device) registration, where cost-effectiveness of scalable product manufacture condition the viability of continued translational research. Such objectives were shown to be attainable using human progenitor cells and should be pursued with variant starting materials, such as equine fetal organ donations and eFPCs banks, with a focus on the ultimate goal of healing equine patients in need of effective and innovative therapies.

\section{Conclusion}

This work establishes technical suitability of eFPCs for consistent, safe and stable cell banking, bioengineered product manufacturing and preliminary safety evidence of allogeneic primary progenitor cell application in hippiatric patients. Successful establishment of robust cell banks allowed for characterization and assessment of stability and cyto-compatibility of eFPCs with collagen and HA bio-resorbable scaffolds, while application in four equine subjects presenting complex wounds yielded preliminary evidence of safety and absence of immunogenicity, tumorigenicity or delayed induction in wound healing. Data presented in this study, along with the vast translational experience available around the use of human progenitor cell types, supports further investigation of eFPC therapy in vivo within standardized veterinary settings and further broadening of potential scopes of application of progenitor cell therapy in the developmental domain of translational musculoskeletal regenerative medicine. Indeed, a single organ donation enables the establishment of quasi indefinite therapeutic cell sources for a variety of musculoskeletal tissue affections, with potential subsequent safe applications in veterinary regenerative treatment strategies for millions of equine patients.

\section{Acknowledgements}

We thank Dr. Arthur Wilkinson for his passionate work with equine patients. We thank Mrs. Judith Applegate for reviewing the manuscript. We thank Baxter AG, Switzerland for the donation of TissueFleece ${ }^{\text {in }}$ and Anteis SA, Switzerland for the donation of Mesolis ${ }^{\mathrm{mm}}$ for these studies. We thank Tec-Pharma SA for the preparation and donation of the equine cell sources for these studies.

\section{Conflicts of Interest}

The Authors have no conflicts of interest to declare.

\section{References}

1. Bertone AL, Sullins KE, Stashak TS, Norrdin RW (1985) Effect of wound location and the use of topical collagen gel on exuberant granulation tissue formation and wound healing in the horse and pony. Am J Vet Res. 46(7)-1438-1444.

2. Koch TG, Berg LC, Betts DH (2009) Current and future regenerative medicine - principles, concepts, and therapeutic use of stem cell therapy and tissue engineering in equine medicine. Can Vet J. 50(2)-155-165.

3. De Schauwer C, Van de Walle GR, Van Soom A, Meyer E (2013) Mesenchymal stem cell therapy in horses-useful beyond orthopedic injuries? Vet Q. 33(4)-234-241.

4. Eggleston RB (2018) Equine wound management-bandages, casts, and external support. Vet Clin North Am Equine Pract. 34(3)-557-574.

5. Maher M, Kuebelbeck L (2018) Nonhealing wounds of the equine limb. Vet Clin North Am Equine Pract. 34(3)-539-555.

6. Bigbie RB, Schumacher J, Swaim SF, Purohit RC, Wright JC (1991) Effects of amnion and live yeast cell derivative on second-intention healing in horses. Am J Vet Res. 52(8)-1376-1382.

7. Roux C (1999) Thesis for Veterinary Medicine, Université Claude Bernard, Lyon, 121.

8. Goodrich LR, Moll D, Crisman V, Lessard P, Bigbie RB (2000) Comparison of equine amnion and a nonadherent wound dressing material for bandaging pinch-grafted wounds in ponies. Am J Vet Res. 61(3)-326329. 
9. Litzke LE, Wagner E, Baumgaertner W, Hetzel U, Josimovic-Alasevic O, et al. (2004) Repair of extensive articular cartilage defects in horses by autologous chondrocyte transplantation. Annals of Biome Engineering. 32(1)-57-69.

10. Carstanjen B, Desbois C, Kekmati M, Behr L (2006) Successful engraftment of cultured autologous mesenchymal stem cells in a surgically repaired soft palate defect in an adult horse. Can J Vet Res. 70(2)-143-147.

11. Lykkjen S, Strand E, Haga HA, Lie KI (2006) Radical surgical resection of locally invasive oro-cutaneous tumors in the buccal region of 2 horses. Vet Surg. 35(4)-319-323.

12. Vidal MA, Robinson SO, Lopez MJ, Paulsen DB, Borkhsenious O, et al. (2008) Comparison of chondrogenic potential in equine mesenchymal stromal cells derived from adipose tissue and bone marrow. Vet Surg. 37(8)-713-724

13. Bussche L, Harman RM, Syracuse BA, Plante EL, Lu YC, et al. (2015) Microencapsulated equine mesenchymal stromal cells promote cutaneous wound healing in vitro. Stem Cell Res Ther. 6(1)-66.

14. Nixon AJ, Sparks HD, Begum L, McDonough S, Scimeca MS, et al. (2017) Matrix-induced autologous chondrocyte implantation (MACI) using a cell-seeded collagen membrane improves cartilage healing in the equine model. J Bone Joint Surg Am. 99(23)-1987-1998.

15. Dahlgren LA (2018) Regenerative medicine therapies for equine wound management. Vet Clin North Am Equine Pract. 34(3)-605-620.

16. Textor JA, Clark KC, Walker NJ, Aristizobal FA, Kol A, et al. (2018) Allogeneic stem cells alter gene expression and improve healing of distal limb wounds in horses. Stem Cells Transl Med 7(1)-98-108.

17. Delco ML, Goodale M, Talts JF, Pownder SL, Koff MF, et al. (2020) Integrin $\alpha 10 \beta 1$-selected mesenchymal stem cells mitigate the progression of osteoarthritis in an equine talar impact model. Am J Sports Med. 48(3)612-623.

18. Winter RL, Tian Y, Caldwell FJ, Seeto WJ, Koehler JW, et al. (2020) Cell engraftment, vascularization, and inflammation after treatment of equine distal limb wounds with endothelial colony forming cells encapsulated within hydrogel microspheres. BMC Vet Res. 16(1)-43.

19. Wainwright DJ (1995) Use of an acellular allograft dermal matrix (Alloderm) in the management of full-thickness burns. Burns 21(4)243-248.

20. Hansbrough JF, Mozingo DW, Kealy GP, Davis M, Gidner A, et al. (1997) Clinical trials of a biosynthetic temporary skin replacement, Dermagrafttransitional covering, compared with cryopreserved human cadaver skin for temporary coverage of excised burn wounds. J Burn Care Rehabil. 18(1Pt1)-43-51.

21. Sheridan RL, Choucair RJ (1997) Acellularallogenic dermis does not hinder initial engraftment in burn wound resurfacing and reconstruction. J Burn Care Rehabil. 18(6)-496-499.

22. Falanga V, Margolis D, Alvarez O, Auletta M, Maggiacomo F, et al. (1998) Rapid healing of venous ulcers and lack of clinical rejection with an allogeneic cultured human skin equivalent. Arch Dermatol. 134(3)-293300 .

23. Kuroyanagi Y, Yamada N, Yamashita R, Uchinuma E (2001) Tissueengineered product-Allogeneic cultured dermal substitute composed of spongy collagen with fibroblasts. Artificial Organs. 25(3)-180-186.

24. Badiavas EV, Paquette D, Carson P, Falanga V (2002) Human chronic wounds treated with bioengineered skin-Histologic evidence of hostgraft interactions. J Am AcadDermatol. 46(4)-524-530.

25. Ichioka A, Kouraba S, Sekiya S, Ohura N, Nakatsuka T (2005) Bone marrow-impregnated collagen matrix for wound healing-experimental evaluation in a microcirculatory model of angiogenesis, and clinical experience. Brit J Plastic Surg. 58(8)-1124-1130.
26. Snyder RJ (2005) Treatment of nonhealing ulcers with allografts. ClinDermatol. 23(4)-388-395.

27. Carter DM, Lin AN, Varghese MC, Caldwell D, Pratt LA, et al. (1987) Treatment of junctionalepidermolysisbullosa with epidermal autografts. J Am AcadDermatol. 17(2Pt1)-246-250.

28. Gallico GG III, O'Connor NE, Compton CC, Remensnyder JP, Kehinde O, et al. (1989) Cultured epithelial auto grafts for giant congenital nevi. PlastReconstr Surg. 84(1)-1-9.

29. Eaglstein WH, Iriondo M, Laszlo K (1995) A composite skin substitute (Graftskin) for surgical wounds. A clinical experience.DermatolSurg 21(10)-839-843.

30. Chan ES, Lam PK, Liew CT, Lau HC, Yen RS, et al. (2001) A new technique to resurface wounds with composite biocompatible epidermal graft and artificial skin.J Trauma Inj Infect Crit Care. 50(2)-358-362.

31. Kaviani A, Perry T, Dzakovic A, Jennings RW, Ziegler MM, et al. (2001) The amniotic fluid as a source of cells for fetal tissue engineering. J Pediatr Surg. 36(11)-1662-1665.

32. Jones I, Currie L, Martin R (2002) A guide to biological skin substitutes. Brit J Plastic Surg. 55(3)-185-193.

33. Kaviani A, Perry T, Burnes CM, Oh JT, Ziegler MM, et al. (2002) The placenta as a cell source in fetal tissue engineering. J Pediatr Surg. 37(7)995-999.

34. Hasegawa T, Suga Y, Mizoguchi M, Ikeda S, Ogawa H, et al. (2003) Clinical trial of allogeneic cultured dermal substitute for the treatment of intractable skin ulcers in 3 patients with recessive dystrophic epidermolysisbullosa. J Am AcadDermatol. 50(5)-803-804.

35. Osswald SS, Elston DM, Vogel PS (2003) Giant right plantar keloid treated with excision and tissue engineered allograft. J Am AcadDermatol. 48(1)-131-134.

36. Wu CH, Chang GY, Hsu CT, Chen RS (2003) Wound healing effects of porcine placental extracts on rats with thermal injury. Brit J Dermatol. 148(2)-236-245

37. Kashiwa N, Ito O, Ueda T, Kubo K, Matsui H, et al. (2004) Treatment of full-thickness skin defect with concomitant grafting of 6-fold extended mesh auto-skin and allogeneic cultured dermal substitute. Artificial Organs. 28(5)-444-450.

38. Fimiani M, Pianigiani E, Di Simplicio FC, Sbano P, Cuccia A, et al. (2005) Other uses of homologous skin grafts and skin bank bioproducts. Clinics Dermatol. 23(4)-396-402.

39. Mostow EN, Haraway GD, Dalsing M, Hodde JP, King D, et al. (2005) Effectiveness of an extracellular matrix graft (OASIS Wound Matrix) in the treatment of chronic leg ulcers-A randomised clinical trial. J Vasc Surg. 41(5)-837-843.

40. Favata M, Beredjiklian PK, Zgonis MH, Beason DP, Crombleholme TM, et al. (2006) Regenerative properties of fetal sheep tendon are not adversely affected by transplantation into an adult environment. J Orthopaedic Res. 24(11)-2124-2132.

41. Hayflick L, Plotkin SA, Norton TW, Koprowski H (1962) Preparation of poliovirus vaccines in a human fetal diploid cell strain. Am J Hyg. 75240-258.

42. Still J, Glat P, Silverstein P, Griswold J, Mozingo D (2003) The use of collagen sponge/living cell composite material to treat donor sites in burn patients. Burns. 29(8)-837-841.

43. Hohlfeld J, de Buys Roessingh AS, Hirt-Burri N, Chaubert P, Gerber S, et al. (2005) Tissue engineered fetal skin constructs for paediatric burns. Lancet. 366(9488)-840-842.

44. Shakespeare PG (2005) The role of skin substitutes in the treatment of burn injuries. Clinics Dermatol. 23(4)-413-418. 
45. De Buys Roessingh AS, Hohlfeld J, Scaletta C, Hirt-Burri N, Gerber S, et al. (2006) Development, characterization and use of a fetal skin cell bank for tissue engineering in wound healing. Cell Transplant. 15(8-9)-823834 .

46. Applegate LA, Scaletta C, Hirt-Burri N, Raffoul W, Pioletti D (2009) Whole-cell bioprocessing of human fetal cells for tissue engineering of skin. Skin PharmacolPhysiol. 22(2)-63-73.

47. De Buys Roessingh AS, Guerid S, Que Y, Berger M, Hirt-Burri N, et al. (2013) Cell therapy assistance in reconstructive surgery for musculoskeletal tissues following burn and trauma-Swiss cellular Transplantation Platform. Def Manag S3-003.

48. De Buys Roessingh AS, Hirt-Burri N, Raffoul W, Scaletta C, Applegate LA (2015) A decade after foetal skin progenitor cell therapy in pediatric burn treatment. J Regen Med 4-1.

49. Abdel-Sayed P, Hirt-Burri N, De Buys Roessingh AS, Raffoul W, Applegate LA (2019) Evolution of biological bandages as first cover for burn patients. Adv Wound Care (New Rochelle). 8(11)-555-564.

50. Abdel-Sayed P, Michetti M, Scaletta C, Flahaut M, Hirt-Burri N, et al. (2019) Cell therapies for skin regeneration-an overview of 40 years of experience in burn units. Swiss Med Wkly 149-w20079.

51. Montjovent MO, Hirt-Burri N, Mark S, Federici E, Scaletta C, et al. (2004) Fetal bone cells for tissue engineering. Bone 35(6)-1323-1333.

52. Montjovent MO, Mathieu L, Hinz B, Applegate LA, Bourban PE, et al. (2005) Biocompatibility of bioresorbable poly (L lactic acid) composite scaffolds with human fetal bone cells. Tissue Engineering. 11(11-12)1640-1649.

53. Quintin A, Hirt-Burri N, Scaletta C, Schizas C, Pioletti DP, et al. (2007) Consistency of fetal cell banks for research and clinical use. Cell Transplant. 16(7)-675-684.

54. Hirt-Burri N, de BuysRoessingh AS, Scaletta C, Gerber S, Pioletti DP, et al. (2008) Human muscular fetal cells-a potential cell source for muscular therapies. PediatrSurg Int. 24(1)-37-47.

55. Hirt-Burri N, Scaletta C, Gerber S, Pioletti D, Applegate LA (2008) Wound-healing gene family expression differences between fetal and foreskin cells used for bioengineered skin substitutes. Artificial Organs 32(7)-509-518.

56. Quintin A, Schizas C, Scaletta C, Jaccoud S, Gerber S, et al. (2009) Isolation and in vitrochondrogenic potential of human foetal spine cells. J Cell Mol Med. 13(8B)-2559-2569.

57. Ramelet AA, Hirt-Burri N, Raffoul W, Scaletta C, Pioletti D, et al. (2009) Chronic wound healing by fetal cell therapy may be explained by differential gene profiling observed in fetal versus old skin cells. ExpGerontol. 44(3)-208-218.
58. Hirt-Burri N, Ramelet AA, Raffoul W, de Buys Roessingh AS, Scaletta C, et al. (2011) Biologicals and fetal cell therapy for wound and scar management. ISRN Dermatol. 2011-16.

59. Darwiche S, Scaletta C, Raffoul W, Pioletti DP, Applegate LA (2012) Epiphyseal chondroprogenitors provide a stable cell source for cartilage cell therapy. Cell Med. 4(1)-23-32.

60. Grognuz A, Scaletta C, Farron A, Raffoul W, Applegate LA (2016) Human fetal progenitor tenocytes for regenerative medicine. Cell Transplant. 25(3)-463-479.

61. Grognuz A, Scaletta C, Farron A, Pioletti DP, Raffoul W, et al. (2016) Stability enhancement using hyaluronic acid gels for delivery of human fetal progenitor tenocytes. Cell Med 8(3)-87-97.

62. Cavalli E, Fisch P, Formica FA, Gareus R, Linder T, et al. (2018) A comparative study of cartilage engineered constructs in immunocompromised, humanized and immunocompetent mice. J ImmunolRegen Med. 2-36-46.

63. Hausherr TC, Nuss K, Thein E, Krähenbühl S, Applegate LA, et al. (2018) Effect of temporal onsets of mechanical loading on bone formation inside a tissue engineering scaffold combined with cell therapy. Bone Rep. 8-173-179.

64. Levinson C, Lee M, Applegate LA, Zenobi-Wong M (2019) An injectable heparin- conjugated hyaluronan scaffold for local delivery of transforming growth factor $\beta 1$ promotes successful chondrogenesis. ActaBiomater. 99-168-180.

65. Laurent A, Hirt-Burri N, Amiot C, Scaletta C, Applegate LA, et al. (2020) Primary progenitor muscle cells for regenerative medicinestandardization of therapeutic protocols and optimized in vivo murine model for volumetric muscle loss. Am J Bio Sci R. 8(2)-143-153.

66. Lapp A, Furrer P, Ramelet AA, Aubort C, Aubort P, et al. (2013) Cellular derivatives and efficacy in wound and scar management. J Cosmet Der Sci Appl. 3-36-45.

67. Pickart LR (1987) Method of healing wounds in horses. Patent. US4937230.

68. DiNapoli L (1998) Magnetic blanket for horses. Patent. US5984855A.

69. Atala A (2006) Recent developments in tissue engineering and regenerative medicine. CurrOpinPediatr. 18(2):167-171.

70. De Coppi P, Bartsch G, Siddiqui M, Xu T, Santos C, et al. (2007) Isolation of amniotic stem cell lines with potential for therapy. Nature Biotechnology. 25(1):100-106.

71. Yingling GL, Nobert KM (2008) Regulatory considerations related to stem cell treatment in horses. J Am Vet Med Assoc. 232(11)-1657-1661. 